$1-1-1952$

\title{
Diseases, insects, and other factors in relation to red clover failure in West Virginia
}

Edward Sumner Elliott

Follow this and additional works at: https://researchrepository.wvu.edu/ wv_agricultural_and_forestry_experiment_station_bulletins

\section{Digital Commons Citation}

Elliott, Edward Sumner, "Diseases, insects, and other factors in relation to red clover failure in West Virginia" (1952). West Virginia Agricultural and Forestry Experiment Station Bulletins. 351T.

https://researchrepository.wvu.edu/wv_agricultural_and_forestry_experiment_station_bulletins/625 


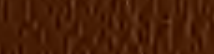

$10,1,5$

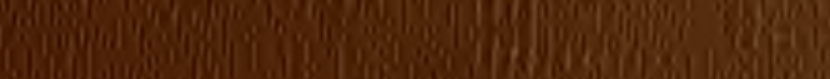

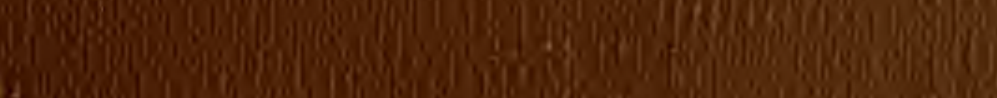

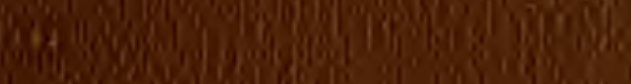

$\operatorname{lig}_{0}$

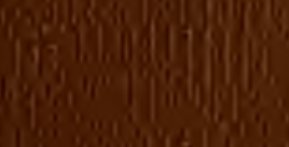

20

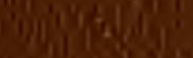

(1) (iin)

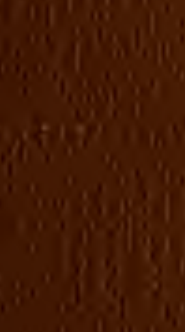

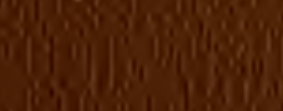
30 in 1 Ion: (4) 1
3,6 (1) 5139

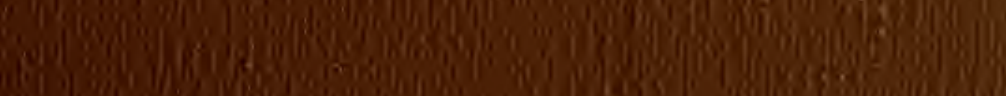
(5)

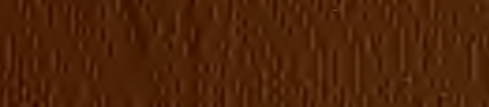
Sing

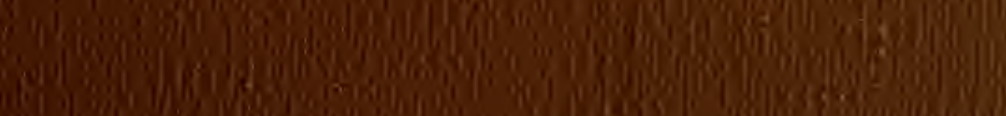
(im) 

Bulletin $351 T$

hriil 1952

\section{Diseases, Insects, and Other}

Factors in Relation to Red

Clover Failure in West Virginia 
EDWARD S. ELLIOTT, author of Diseases, Insects, and Other Factors in Relation to Red Clover Failure in West Virginia, was formerly a Research Assistant in Plant Pathology at the West Virginia University Agricultural Experiment Station.

WEST VIRGINIA UNIVERSITY

Agricultural Experiment Station

College of Agriculture, Forestry, and Home Economics

H. R. VARNEY, Director

MORGANTOWN 
Diseases, Insects, and Other

Factors in Relation to Red

Clover Failure in West Virginia

By Edward S. Elliott

WEST VIRGINIA UNIVERSITY AGRICULTURAL EXPERIMENT STATION 


\section{CONTENTS}

SUMIMARY

INTRODUCTION

LITERATURE REVIEW

INSECTS ..

Insects that Injure Both Clover Hay and Seed Crop 23

Insects that Damage Only the Red Clover Seed Crop 29

Insecticide Control of Insects Damaging Seed Crop.

DISEASES 37

Diseases that Cause the Death of Mature Plants 38

Diseases that Ordinarily Do not Kill the Plant 41 BLACKPATCH

Characteristics of the Blackpatch Fungus

Effect of Weather Conditions on the Disease in Eastern West Virginia

Plant Parts Affected $\quad 50$

Seed Transmission 55

Influence on the Seed Yield 58

Control 60 


\section{SUMMARY}

Many problems are involved in the utilization of red clover as a part of the crop rotation system used in West Virginia. One major requirement is to maintain a good clover stand until the second-year harvest is made. In the seed-producing region of eastern West Virginia there is an additional problem of increasing and stabilizing the seed yield.

In addition to the cultural practices that may influence the growth of red clover, several other factors are involved. These include weather conditions, varietal differences, insect pests, and diseases. A major part of this work has centered on a study of the insect pests and diseases that affect the red clover crop.

Extended periods of both wet and dry weather affect the plant adversely. Climatic conditions often have an even greater influence on the red clover hay and seed crops by their indirect effect on the insects and diseases that injure it. Frost heaving and freezing damage results in extensive losses since the periodic freezing and thawing is usual during the winter months.

A marked difference has been noted in the growth of several new red clover varieties under northern West Virginia conditions. Strains that have been grown in the seed-producing region for many years often are as good as some of the more improved varieties. Home grown seed has been recommended for the region by extension specialists because it was believed to be better adapted through a process of natural selection. The present study has indicated that the blackpatch disease is a major factor in the seed-producing region and may affect the recommendation for home grown seed in the future.

A large number of insect species cause extensive injury to both the hay and seed crops. In West Virginia, the most important of these are meadow spittlebug, tarnished plant bug, clover root borer, clover root curculio, clover leaf weevil, and several species of leaf hoppers, aphids, grasshoppers, and mites.

The feeding habits of another group of insects result in extensive injury to the flower parts and reduce the seed yield. This group includes three species of flower weevils that are very common in West Virginia. The clover seed-chalcid and the cloverflower midge also are common and may cause considerable losses. 
Some red clover plots treated with the insecticides DDT, methoxychlor or sabadilla, yielded more seed than untreated plots, but increases were not consistent. A majority of the treated plots did not give any significant increase over the untreated check plots.

Damage caused by diseases is equal or greater than that caused by insect pests. Fusarium root rot and Sclerotinia crown rot in the region cause considerable thinning of clover stands because of the number of plants killed. Fusarium root rot, which generally is associated with the injuries caused by the clover root borer and clover root curculio, is most destructive during the second year of growth.

A number of other diseases do not ordinarily kill red clover plants but often are responsible for extensive defoliation that would affect the quantity and quality of the hay. Several diseases of this type are common in West Virginia; they include black stem, Stemphylium leaf spot, powdery mildew, Pseudopeziza leaf spot, sooty blotch, and rust. Northern anthracnose and southern anthracnose, destructive in many sections of the country, have not been common in West Virginia during the period of this study.

The blackpatch fungus of clover and other legumes, heretofore known to be parasitic only on leaves and to cause only minor damage, has been found to be strongly pathogenic to stems and flowers of red clover and to be a limiting factor in seed production in West Virginia. The disease was prevalent on both firstand second-year clover, but was most destructive on the secondyear seed crop in which the stems and flower heads were affected. The greatest damage resulted from the girdling of the stem beneath the flower head before the seeds were mature, or from direct infection of the flowers before the seeds were fully formed. Injury was most severe from midsummer to harvest and was favored by high humidity.

The blackpatch fungus has been isolated from two-year-old clover seeds. This indicates that it survives the winter in or on the seeds from infected plants. The fungus may cause a dampingoff of seedlings if it is present on the seeds at the time they germinate. Some evidence indicates that the organism may winter in the field on clover straw or in the soil, but no proof of this has been obtained. It has been observed, however, to live over winter on infected seeds in the soil and to appear early in the season on volunteer seedlings. 
Seed harvested from red clover heads that had been attacked by the disease was only about half the quantity obtained from heads on plants free of the fungus.

Greenhouse tests indicated that the disease could be controlled by the use of certain fungicides. Field tests, to determine if the seed yield could be increased by controlling the fungus, were inconclusive. The incomplete and inadequate information about blackpatch and the obvious reduction in seed yields that it causes would seem to justify a more intensive study of the disease. Fungicides and insecticides have not been used extensively on clover fields. The amount of injury caused by blackpatch as well as other diseases and insects would seem to justify extensive experiments. It should be possible, by the use of the right combination of fungicides and insecticides applied at the proper time, to reduce the damage from several diseases and insects and increase the yields of both hay and seed. 


\section{INTRODUCTION}

In certain sections of West Virginia the second cutting of red clover often is harvested for seed. Usualiy satisfactory yields are obtained. In some years, however, the seed yields are very low even when stands are good and weather conditions are apparently favorable. Poor stands and consequent low seed yields often result from planting seeds of poorly adapted varieties. However, in one area, centering around Mineral, Hardy, Grant, and Pendleton counties, many of the farmers have maintained the same strain of clover for many years, but many unexplained seed failures have occurred in such locally grown strains that should have been well adapted. The erratic behavior of seed yields in this region led to a request that the West Virginia University Agricultural Experiment Station make a study of clover failure. The Department of Plant Pathology and Bacteriology undertook an investigation of the factors contributing to clover failures in West Virginia with particular reference to seed production in the above counties.

Although some attention has been given to cultural practices and weather conditions in evaluating the various factors contributing to clover failure, particular attention has been given to diseases and insect pests.

In the three-year crop rotation system used extensively in West Virginia, red clover meadows, when properly utilized, have been a means of building soil fertility so that more corn, wheat, and oats could be produced. In addition, it also provides crops of hay, seed or silage, and when mixed with other legumes and grasses, produces excellent pasture in some regions.

In conjunction with the program to improve farm crop production in general, there is need for preventing losses often encountered in growing red clover. In West Virginia this need gives rise to two distinct problems; (a) for the State in general, to maintain the stand of clover until the second-year harvest is made, and (b) for the seed-producing region, to increase the seed yield. If the uncertainty in red clover production could be removed, use of this legume would increase immensely. In turn, the productivity of the soil on which red clover is grown, if properly managed, also would be raised.

Any adverse factors that may affect the stand and the hay yield may likewise affect the quantity of seed harvested. In addi-

NOTE: This bulletin is based on a thesis submitted to the Graduate School of West Virginia University in partial fulfillment of the requirements for the Ph.D. Degree. 
tion, several other factors are involved in seed production. Even though the seed yield problem has been the major consideration in this work, a survey of some of the factors that cause the death of plants or a decrease in vigor was necessary. Factors that tend to reduce the vigor of the plant and those concerned directly with seed production must both be considered in determining which are the most important in reducing the seed yield. The factors limiting the production of red clover in West Virginia can be grouped under the following headings: soil types, nutritional level, $\mathrm{pH}$ of the soil, cultural practices, weather conditions, varietal differences, and insects and diseases.

Although many soils in the clover belt are not adapted to red clover culture, most of the land now used in the production of small grains also will support clover. The water-holding capacity would probably be the main factor determining whether a soil would or would not support growth of this legume. Dry, sandy or shale soils or those lacking adequate drainage are not favorable.

Nutritional level of the soil also is important. When one can neglect the requirement for nitrogen, there may be a tendency to ignore the requirements for phosphorus and potassium. These requirements will vary, depending on the type of soil, but sufficient amounts must be present before the desired results can be obtained. Likewise, sufficient lime must be available to maintain the $\mathrm{pH}$ level required by red clover.

Cultural practices vary from region to region and are determined by years of practical application and evaluation of the results obtained. Use of the grain dril! has largely supplanted hand seeding. This has resulted in better and more uniform stands and furnishes a more satisfactory means of applying any additional fertilizer requirement.

The time of seeding is quite variable, depending on the weather and other factors. Clover is generally seeded in late winter or during spring, the main considerations being workable soil and a date early enough to allow the seedlings to reach some size before any dry weather occurs.

It is common for growers to "clip" the clover fields with a mowing machine sometime during late summer or early fall of the first year. In addition to solving in part the weed seed problem, it brings to the ground the longer grain straw left by the binder or combine used for harvesting the grain. This is known to benefit the clover, provided it is not done too late in the fall. It is necessary to clip early enough to allow the plants to recover vigor 
before going into winter dormancy. Occasionally a clover field makes sufficient growth to provide a cutting of hay during the first year. This also should not harm the stand to any extent if the necessary time is allowed for recovery of the plants before freezing weather begins. Since winter may be the most critical period for red clover, the plant should be healthy and vigorous before that period begins.

Studies in Iowa by Wilsie and Hollowell (49) and similar studies in Ohio (48) and Michigan (32) have shown that the stage of growth at which the first crop is cut has a marked effect on the quantity and quality of forage and seed produced at the second cutting. To obtain the highest forage yield, Wilsie and Hollowell recommend that the first crop be cut at the late-bloom stage and the second crop at the full-bloom stage. Seed production is favored by cutting the first crop for hay at the early-bloom stage. This observation probably will not always hold true, since seed setting also is influenced by many other factors. Cutting the hay crop from fields to be harvested later for seed often is delayed in West Virginia by weather conditions. It would appear that cutting earlier than the early-bloom stage would be advisable in some instances.

Owing to the many types of farm land in this State on which red clover is grown, practices that give best results in one area may not apply to other sections. The individual farmer will gain much by trying new ideas on a small scale and by utilizing those that prove to be of value.

Weather conditions have a profound effect on growth and seed production. From the time that the seed is planted until the plant dies, growth and reproduction are more or less dependent on the vagaries of the weather. Drought may kill the plants during some periods or may so weaken them that they are more susceptible to attacks by insects and diseases. Similarly, wet weather may predispose the plants to some of the most severe diseases. Botanically, red clover is a perennial, but due to the climate in this region and its indirect effect on insects and diseases, the plants behave as biennials. Few of the plants seeded remain after the winter of the second year.

It has been noted that seed production is lowered by periods of wet or cool weather during the flowering period. The bees required to pollinate the flowers are inactive during such periods, therefore fewer seed are formed.

West Virginia is in a region of periodic freezing and thawing 
during the winter months. In addition to injuring the plants by heaving, these conditions also cause loss of vigor and favor attacks by root rot organisms. The severity of this type of damage may depend on the properties of the soil; thus selection of a good site or correction of soil deficiencies is of importance.

In recent years several new varieties or strains of red clover have been introduced by state and federal improvement programs. These varieties have been developed to meet the needs of the various regions for clover having specific qualities such as resistance to some of the more severe diseases. The possible value of locally produced seed for an area also has been realized, particularly if the grower has saved his own seed year after year. It is believed that by natural selection, a strain of clover better adapted to the requirements of the area will be developed over a period of years. For this reason, growers in the seed-producing region of West Virginia have been encouraged to maintain their home grown strains until improved varieties definitely superior to their own are introduced.

It has become increasingly evident that red clover is plagued by numerous diseases and insects. Damage caused by a single pest may, if great enough, affect the yield of hay or seed. Generally, however, numerous pests are present. Each causes some damage to the plant, so that by harvest time only a fraction of the potential crop remains. This type of damage is much less noticeable and one fails to realize what the total yield might be if the plants were free of diseases and insect pests.

Studies have been made in recent years on methods of controlling some of the insect pests of clover. The problem is great because of the large number of species associated with clover and the long period during which the injury may be caused. If hay and seed yields could be increased consistently, dusting or spraying with an insecticide might be feasible. However, satisfactory methods of application, considering also time, equipment, and cash outlay, would be necessary for general acceptance by the usual farm seed producer in this State.

Because of the difficulties in applying fungicides to red clover, control of diseases has been almost exclusively through use of resistant varieties. Several strains of clover have been produced that are resistant to individual diseases, but the process of developing new strains resistant to disease which retain other desirable traits is slow. The necessity and apparent practicability of using insecticides to control certain insects may lead to the addition of 
fungicides to the dust or spray material to control some of the more serious diseases.

Seed production in the eastern part of the State would be an important industry if the quantity of seed produced yearly could be increased and stabilized. A satisfactory marketing system for clover seed cannot be built up if a large yield is secured one year to be followed by a very low yield the next year. Fluctuation in yield has been evident in the area at the centrally located seed cleaning plant that cleans practically all of the seed grown in the region. Red clover seed processed at the plant from 1940-48 has been as follows:

$\begin{array}{rrrr} & \text { Lbs. } & & \text { Lbs. } \\ 1940 & 31,831 & 1945 & 45,000 \\ 1941 & 30,271 & 1946 & 95,000 \\ 1942 & 5,540 & 1947 & 79 \\ 1943 & 79,905 & 1948 & \end{array}$

The principal aim of this study has been to ascertain what factors are responsible for this fluctuation in seed yield, since it cannot be explained on the basis of the acreage grown. It is evident that some of the factors responsible for decreasing the seed yield also are responsible for failures in the hay crop. Both hay and seed production have been considered because they are so closely related.

\section{LITERATURE REVIEW}

Records of the difficulties encountered in growing red clover in both Europe and America extend back more than 200 years (12). The common occurrence of these difficulties has led to the use of such terms as "clover sickness" and "clover failure" to describe the condition, regardless of the cause.

Owing to the variation in soil and climatic conditions in this country, it often has been found that the factors responsible for failures in one area may not apply to those in other states or regions. For this reason, it has been necessary to make individual studies to determine the local factors leading to clover failure. Thus, in this country alone, many studies have been made and a large number of factors designated as contributing to clover failures. 
Extensive studies in Kentucky have pointed out some of the factors involved there. Fergus and Valleau (12) reported that clover failure results indirectly from unfavorable nutritional environment and directly from the attack of pathogenic organisms upon the roots. Possible causes of failure due to soil conditions included low or unbalanced fertility, unfavorable $\mathrm{pH}$, and poor aeration. Numerous species of Fusarium were found to cause root rots of red clover, but this was believed to be a critical factor only when environmental conditions were unfavorable to continuous growth of the plant.

Fergus (11) later included poor soil, southern and northern anthracnose, crown rot, potato leaf hopper, and winter-killing as major factors causing clover failure in Kentucky. Winter-killing was thought to be the most common cause of failure. Drought was not considered as a major factor unless it occurred within the first few weeks after seeding. Mature plants were found to survive drought unless attacked by insects or diseases.

Pieters (36) has listed the following as causes of clover failures in the United States: unsuitable soil conditions; unadapted or poor seed; poor methods of seeding; diseases and insects; and wrong fall treatment the first year. Well-drained soil was pointed out as being a primary requirement of red clover. In addition, sufficient phosphorus, potash, and organic matter must be maintained. In regions where bases are leached from the soil, additional amounts of lime must be added to maintain the high $\mathrm{pH}$ level required by clover.

Among the diseases and insects reported by Pieters as causes for clover failures were root borers, anthracnose, and stem and root rots. Proper liming and fertilizing of the soil were offered as the best ways to combat these pests on red clover; vigorous plants would be less likely to succumb to the attacks of insects and diseases.

Overgrazing and cutting too late in the fall of the first year was reported as a major cause of loss through winter-killing. Permitting the clover to grow the first year until a hay crop can be harvested usually allows too little time for the plants to recover before winter.

Heusinkveld (18) has attributed red clover failures in Illinois to one or more of the following causes: (a), unadapted or poor seed; (b), lack of inoculation; (c), wrong methods of seedbed preparation; (d), soil acidity and lack of plant nutrients; (e), competition of grain crops and weeds; (f), improper management the 
first season; (g), insects and diseases; (h), drought; and (i), winter-killing. Clover failures in Illinois have been more frequently attributed to a lack of lime in the soil than to any other condition.

Pieters and Hollowell (35) have divided the clover belt into three regions on the basis of the limiting factors to which the plant must become adapted. The chief limiting factors in the southern region are diseases such as southern anthracnose (Colletotrichum trifolii). This region includes Tennessee, Kentucky, Maryland, and parts of North Carolina, Virginia, New Jersey, Ohio, Indiana, Illinois, and Missouri.

Red clover grown in the central region, which extends from the southern region to approximately the latitude of the IllinoisWisconsin boundary, must be both disease resistant and winter hardy. Low temperatures and little snow cover during the winter are common in that region.

The northern region extends from the Wisconsin-Illinois line to the Canadian border. Diseases are less destructive in this region, but clover must be capable of tolerating a long period of dormancy, which may at times be accompanied by very low temperatures.

Pieters and Hollowell state that the severity of adverse factors in each of these regions varies from season to season and according to location. They believe that one of the principal causes of the dying out of red clover during the second winter is the injury produced by the clover root borer (Hylastinus obscurus Marsham).

Hollowell (21) highly recommends use of the newer adapted varieties. Dollard, a variety with some resistance to northern anthracnose, is recommended for the northern region. Midland has given good yields in the eastern and southern parts of that region. Midland also has produced well in the central region. For the South, varieties such as Kenland, Cumberland, Kentucky 215, and Tennessee Anthracnose Resistant have given the best results.

Hollowell also points out that strains of red clover that have been propagated on the same farm for many years also serve as a good source of seed for that region even though they may not have any noticeable disease resistance.

One of the principal causes of clover failure before 1926 was the use of unadapted foreign seed (20). This seed was generally not as winter hardy or as resistant to diseases and insects as that grown in this country. An amendment to the Federal Seed Act in 1926 provided that imported seed was to be stained as an indication of its origin. Domestic grown seed has almost wholly replaced the use of foreign seed in recent years. 
Any conditions that cause clover failure would likewise affect the amount of seed produced, but some additional factors must be considered. Bees are essential for pollination since red clover is practically self-sterile. Some of the literature on the relation of bees to red clover seed production has been reported by Thompson (42). Studies made by Megee and Kelty (31) and similar studies from other regions have shown that the amount of seed set is in proportion to the number of bees present. Domestic bees are of the greatest importance because of the scarcity of bumblebees in some locations. Bird (5) concluded that in Canada the number of bumblebee visitors was a much more important factor in seed setting than the number of honey bee visitors or the number of florets per head. He also reported that red clover brought into full bloom in late July or early August has a much better chance of receiving satisfactory pollination than at any other time.

The literature available on red clover culture, insect pests, and diseases is voluminous. In most cases, however, the studies have been made on single problems, such as the effect of a disease, or an insect, on the crop. General studies are few and, in many cases, very brief.

\section{EFFECT OF WEATHER ON RED CLOVER}

Farmers usually place the responsibility for clover failures on weather conditions. Although the farmer may not realize the total influence weather conditions may have on the clover plant itself, on diseases and insect pests, on pollinating insects, and even on the soil, he is able to observe that failures often follow certain abnormal periods.

Red clover is a moisture-loving crop. Therefore, culture is restricted to an area of fairly high rainfall. The literature indicates that clover diseases are the limiting factor on the southern boundary of the clover belt, lack of water on the western boundary, and low winter temperature in the North. The diseases that limit the southern boundary are in turn directly affected by the weather, particularly some of the more injurious ones such as anthracnose and crown rot.

In addition to the indirect effects of weather on the clover crop, such as the effect of weather on diseases, several other conditions have a direct influence on the growth of the plants. Dry weather, excessively wet weather, and winter freezing and thawing limit normal growth. 
Excessively dry conditions have not been a factor in West Virginia during the period of this study except in very limited areas. In some instances this has been intensified by soils having a low water-holding capacity. Seedling plants have been observed to die soon after germination of the seed planted in the spring, the first few days after germination being the most critical. Clover planted with spring oats is more exposed to drought than when drilled in winter wheat. Until the loose soil in which oats is planted is wet by rains, it dries out very rapidly, particularly if the organic matter content is low. After the soil is packed around the seed by rainfall, there is little chance for excessive drying except by extremely dry weather.

The period just following the cutting of the first hay crop is apparently critical. Numerous instances have been observed in which a large percentage of the plants in a field failed to recover. Normally, new growth begins as soon as the first hay crop is removed and the plants bloom again within a month. In several of the cases in which many plants died following cutting, the soil was excessively dry. Examination of the roots in most instances failed to show other causes for death.

The major effect of dry periods on clover in West Virginia is to reduce growth and to make the plants more susceptible to injury by certain diseases and insects. Severe droughts occur so seldom in this region that they cannot be considered as a major limiting factor.

Death of red clover plants as a direct result of extended wet periods has seldom been observed in this State. Soil in low areas having insufficient drainage may become so saturated during wet seasons that the clover dies. This may be due to insufficient aeration and the interruption of normal plant processes or to invasion by parasites after the plant has been weakened.

Clover makes rapid growth when ample water is present. Plants generally lodge during the flowering period if there is extensive top growth and wet conditions. After the stem falls to the ground, the lower part of the plant is more subject to attack by leaf and stem diseases. Defoliation of the lower part of the plant usually occurs as a result of high humidity present at ground level. Lodged clover is much more difficult to harvest and the quality is not equal to that which remains standing.

The amount of seed produced also is affected by extended periods of wet weather. Hollowell (19) found that soil moisture, whether low, medium, or high does not prevent the setting of 
seed, but does affect the amount of plant growth and the number of heads produced. Atmospheric humidity also did not affect the setting of seed directly, but bees were found to be most active during periods of dry weather.

Lack of pollination of clover by honey bees and bumblebees may be one of the important limiting factors at some locations in West Virginia. Heavy rainfall occurred during the summers of 1948 and 1949 at the time the seed crop clover was flowering. That period was characterized by wet, cloudy days and included only a few of the hot, bright days required for maximum bee activity. Relatively few bees were active in the fields during the flowering period, indicating that lack of pollination may be the reason for small seed yields in some cases.

Many of the clover diseases become more injurious during periods of wet weather. Even though most diseases do not affect the blooms directly, they may cause sufficient damage to the stems and leaves to reduce the number of heads produced and thereby decrease the quantity of seed. This has been noted especially in clover that has lodged. The plants often have extensive stem growth but few leaves remain on the lower parts and few blossoms are present. Stemphylium leaf spot is the most common disease causing defoliation of the lower leaves. Black stem (Phoma trifolii Johnson and Valleau) also may cause extensive stem and leaf injury and reduce the vigor of the plants affected.

Although anthracnose was observed only rarely during the period of this study, potentially it is one of the most severe diseases affecting the clover seed crop. Since severely infected plants seldom flower, there would be little possibility of obtaining high seed yields from heavily infected fields. The moist, warm weather was favorable for development of anthracnose during the summers of 1948 and 1949, but neither northern nor southern anthracnose appeared during that period.

West Virginia is in a region subject to periods of alternate freezing and thawing during the winter months. This condition is far more injurious to plants than continuous freezing temperatures. Snow-cover protection of the plants is seldom present. One result of the freezing and thawing is extensive heaving of the soil. This causes parts of the tap roots of red clover to be exposed to the weather. This condition is most severe in low, heavy, poorlydrained soils, but has occurred to some extent on all soils. Pressure exerted on the crown and roots of the plant by the expanding, freezing soil may break the lateral roots and even the tap root. 
As the roots are broken or loosened, the plant crown is forced up to above normal ground level. During periods of thawing, the top soil returns to its normal level, leaving the upper root system exposed. The amount of the root system exposed varies. In some cases it is not enough to cause the death of the plant, but such plants are often killed by root-rotting fungi. Red clover plants injured by frost heaving are shown in Figure 1.

A number of factors have been observed that may influence the severity of this type of injury. Soil covered by a mat of organic matter such as leaves and straw is seldom subject to heaving. Cooper (8) noted that the damage to transplanted seedlings of black locust by frost heaving was in direct proportion to the ground cover. Unprotected locust seedlings were forced from the soil more than three inches in some cases.

The type of soil and its water content also influence heaving. The number of times that freezing and thawing occur during the winter months is an additional factor.

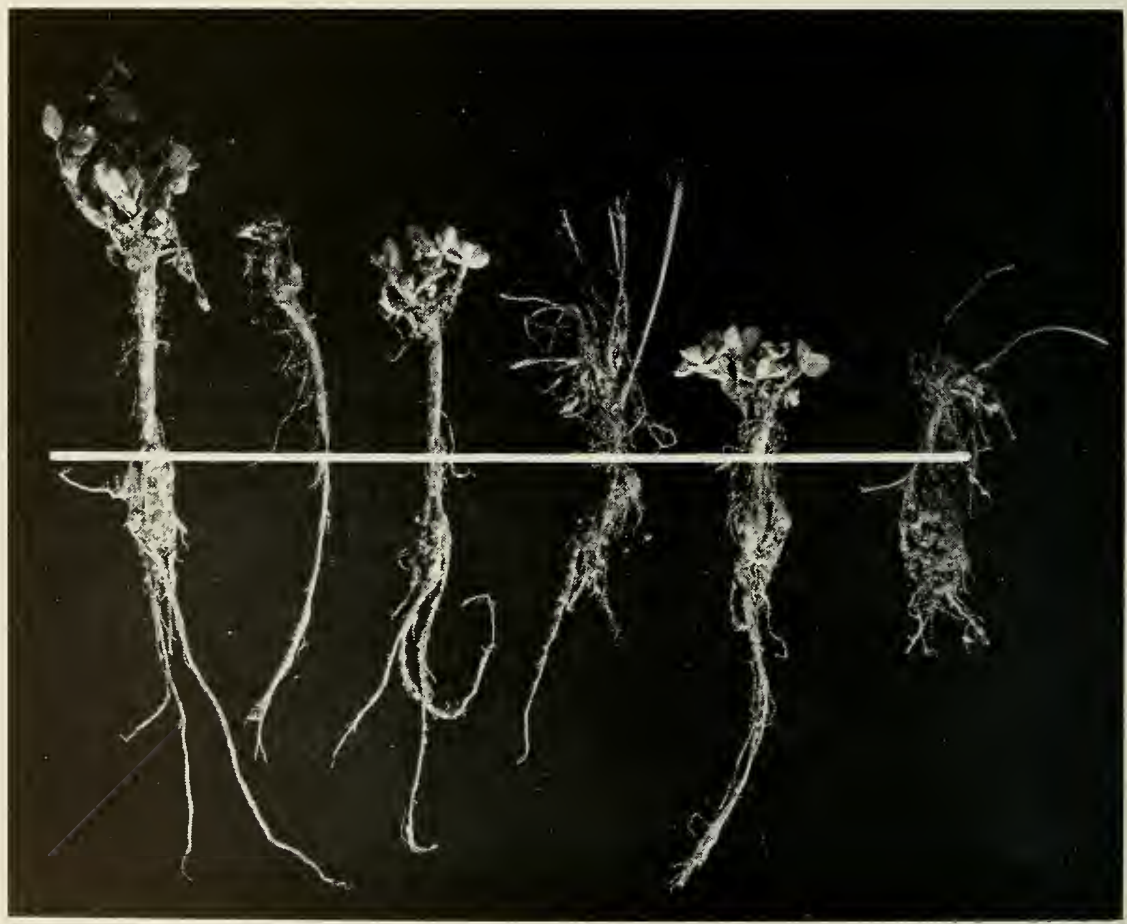

FIGURE 1. RED CLOVER plants showing different degrees of frost heaving. White line indicates location of soil surface at time the plants were collected. 
Red clover roots injured by insect feeding (i.e., clover curculio and clover root borer) or weakened by disease would likely be more susceptible to heaving injury. Likewise, vigorous plants injured by frost heaving appear to be more susceptible to infection by diseases, particularly Fusarium root rot.

Winter injury is not necessarily confined to results of heaving. The crown and upper root system may be injured by freezing even though the plant is not lifted above normal soil level.

Fenne (10) reported extensive damage to red clover fields in northern Virginia by species of Fusarium and Rhizoctonia following severe winter injury.

Extensive winter injury to red clover has been found in the entire northern West Virginia area. Injury has varied from slight to severe, depending on conditions during the winter months. In some cases, the dying plants were scattered. This resulted in a general thinning of the stand. Other localized areas, usually occurring on poorly-drained soils, often were devoid of living clover plants by spring. Thin stands are more susceptible to winter injury because there is less vegetation to protect the soil from alternate freezing and thawing.

No satisfactory means of controlling winter injury has been reported. Application of a protective cover would be practical only in small fields. Heusinkreld (18) reported that a straw mulch provided some protection against cold and tended to prevent heaving, but considered this method to be impractical for large fields.

\section{VARIETAL DIFFERENCES}

For several years the Agricultural Extension Service in West Virginia has recommended that farmers utilize home grown seed on the assumption that it would be better adapted to the local conditions than seed brought in from other regions. Reports from other states have indicated that their locally produced seed is superior to foreign seed or domestic seed from certain other regions. Fleetwood (13) reported that domestic seed seemed to be the best under Missouri conditions. He found that the domestic seed was superior to foreign seed and in some cases gave better yields than the improved varieties Cumberland and Midland.

Aamodt et al. (3) recommended use of domestic seed at a reduced seeding rate in Wisconsin during the seed shortage of 1937 rather than to mix quantities of foreign seed with it. Tests indicated that Wisconsin produced seed that was far superior to 
foreign seed for that region and, in most cases, superior to seed from other states. It was indicated that use of the cheaper foreign red clover seed in mixtures of domestic seed would result in less well-adapted plants from future seed generations.

Fergus (11) stated that the apparent solution of the clover failure problem in Kentucky was in the use of varieties that had become adapted to Kentucky conditions by years of natural selection within the state.

In West Virginia certain local red clover seed strains have been maintained on the same farm for many years. In some cases, where the seed has been passed on from generation to generation, the age of the strain cannot be determined, but fifty years would be a conservative estimate. In most instances in which unfavorable conditions have caused the loss of the seed crop, additional seed is obtained from growers in the same area. Thus, the red clover seed brought into some areas of West Virginia many decades ago may still serve as a basis for much of the seed produced.

Within recent years agencies in several parts of the clover belt have developed strains believed to be superior in some respects to previously available types. These have been propagated chiefly because of known resistance to certain of the serious clover diseases. In addition to disease resistance, other desirable traits have been incorporated whenever possible. As should be expected, none of the new strains or varieties can be used as a universal preventive for clover failures, but they are of great value in regions having frequent outbreaks of certain diseases.

A number of the improved varieties have been planted in plot trials at several locations in northern West Virginia. Reaction of the different varieties to disease has been the primary consideration, but other agronomic characteristics also have been noted. For comparative purposes, two strains of red clover from West Virginia farms were included. Both of these strains had been grown on the same farms for many successive seed generations. The improved varieties included Wisconsin Mildew Resistant, Kenland, Cumberland, Midland, New Hampshire, Tennessee, Dollard, and Ottawa.

Striking differences were evident in the stands the second year after planting. The reduction in stands was not caused by the same factors at each location. Although diseases, particularly Sclerotinia crown rot, were responsible for some of the reduction in stand in each case, this reduction appeared to be uniform regardless of the variety used. No northern or sourthern anthracnose was present 
at any of the variety trial locations, so no comparison could be made on the basis of resistance to these diseases. Since disease resistance apparently was not a primary factor, differences between the stands were probably due to variation in the winter hardiness of the varieties concerned.

Winter injury was especially evident in the variety Wisconsin Mildew Resistant. Very few plants remained in the plots by spring of the second year. Although this variety was very resistant to powdery mildew, its lack of hardiness would prevent its utilization in this area.

One of the West Virginia strains tested proved to be as good as the best of the improved varieties in regard to the stand present during the second year. The second West Virginia strain was not equal to the first, but was still superior to some of the improved varieties. A summary of the stand on all plots for both the first and the second year of growth is shown in Table 1.

The results presented would indicate that in West Virginia some locally grown strains may be as good as the new improved varieties. Some improved varieties having resistance to certain diseases such as northern and southern anthracnose would undoubtedly be superior in any region in which outbreaks of those diseases were common. Growers should not replace home grown red clover strains with the new improved varieties unless they have been proven definitely superior in that area or unless there is some specific reason for doing so.

table 1. Comparison of Plot Trials of Improved Red Clover Varieties and West Virginia Farm Strains on the Basis of First- and Second-Year Stands

\begin{tabular}{|c|c|c|}
\hline VARIETY OR STRAIN & $\begin{array}{c}\text { 1ST-Year Stand } \\
\text { IN SEPTEMBER }\end{array}$ & $\begin{array}{c}\text { 2ND-YEAR STAND } \\
\text { IN JULY }\end{array}$ \\
\hline Wisconsin Mildew Resistant & $3^{*}$ & 1 \\
\hline Kenland & 4 & 3 \\
\hline Cumberland & 4 & 2 \\
\hline Midland & 4 & 2 \\
\hline New Hampshire & 2 & 1 \\
\hline rennessee & 2 & 1 \\
\hline Dollard & 2 & 1 \\
\hline Ottawa & 2 & 1 \\
\hline Grove Strain (W. Va.) & 4 & 3 \\
\hline Lambert Strain (W. Va.) & 3 & 2 \\
\hline
\end{tabular}

*Stand of plants in plots are rated as follows: (1) poor, (2) fair, (3) good, and (4) excellent. 


\section{INSECTS}

The injury caused by insect pests is undoubtedly one of the major factors to be considered in a study of clover failures. No part of the plant is immune to injury; some insect species feed on the parts above ground, some on the roots, and others may even be restricted to individual organs such as the ovaries in the flower heads.

Only a few of the many insects that attack red clover are restricted to the floral parts and affect only the seed crop. Even though a majority of the insect pests feed on the foliage and roots, they also indirectly affect the seed yields; their feeding results in less vigorous plants and fewer flowers. Thus, to increase seed production by controlling the insect pests, one must consider not only those pests known to attack the floral parts, but also those responsible for killing or reducing the vigor of the plants.

Even though these insect pests have been known for many years, few practical control measures have been developed. Until the last few years, control depended largely on cultural practices aided by natural enemies of the insects. The rapid development of improved insecticides, especially the "residual insecticides," and the increased interest in their use in the last decade has resulted in numerous studies on the effectiveness of these materials in controlling certain of the insect pests of red clover.

In some cases more detailed data on the habits and life histories of the insects will be required before control by insecticides will give maximum results. The most effective material as well as the proper time to use it is often in doubt. The life history of certain insects, particularly in regard to wintering and number of generations per year, may not be the same in the different regions. This would necessitate a separate study in each region to obtain data necessary to make a control program more than a "hit and miss" measure.

Another problem in seed production is that of controlling the destructive insects without affecting the bee population required for pollination. Some of the insects may cause their greatest damage when the clover is in bloom and the bees are active. In such cases, the desired solution would be to free the fields of the injurious insects at some other time during their life cycle. Here again, a thorough knowledge of the insect's life history would be required to determine other periods when it might be controlled. 
It is difficult to obtain even a rough estimate of the injury caused to red clover plants by certain insects. In some instances there is visual evidence of injury, such as blasted flower heads and damaged leaves, that can be assigned to the feeding of specific pests. In most cases, however, the damage to individual plants is the result of feeding by several species. Generally, it is impossible to determine what part of the total injury is caused by each individual species. This is particularly true of injury caused by insects such as the leaf hoppers, spittle bugs, tarnished plant bugs, and others of a similar nature.

The minute size of certain pests such as clover-seed midge and clover-seed-chalcid poses another probiem in determining the extent of damage caused. A survey of the adult population seems to be the only practical approach, and even that would be very time consuming.

For convenience, the insects observed in northern West Virginia have been divided into two groups, (a) those that injure both the hay and the seed crop, and (b) those that affect only the seed crop. Data on extent and type of injury caused by insects as well as their period of activity are given, whenever possible, in the following discussion.

\section{Insects That Injure Both Clover Hay and Seed Crop}

\section{Meadow Spittlebug. Philaenus leucophthalmus (L.)}

Observation and reports from farmers indicate that this insect is on the increase in some sections of West Virginia. In most fields of red clover, few plants can be found in the spring that do not have at least one spittle mass somewhere on the new growth. Often one plant is covered by many spittle masses, each enclosing from one to a dozen or more nymphs. Egg masses hatch at about the time the plants break winter dormancy. Newly-hatched nymphs are orange yellow, but they change to a light green as they grow. The adults appear during late May or early June, generally before the first hay crop is harvested.

Evidence of injury to the clover by these insects has been noted. Stunting of the plants that show masses of spittle is common. The extent of stunting often is in proportion to the number of spittle masses or nymphs on the plant. This has been observed mainly during the early growth of the plants. The stunting can be attributed to this insect since during that period few other injurious 
insects are present. In addition to the injury caused to the foliage, Scholl and Medler (38) found that less seed was produced by alfalfa if adult spittlebugs had fed upon the blossoms. Since populations of the spittlebug are very high in most areas of West Virginia there is little doubt that it contributes to the reduction in both hay and seed.

Weaver (45) found that spraying with benzene hexachloride effectively controlied the nymphs and increased the hay yield up to 44 per cent in large-scale tests. Early treatment was found definitely necessary for achievement of maximum results. Gamma isomer of benzene hexachloride (Lindane) at the rate of 2 to 3.2 ounces per acre was used for the large-scale tests.

Considering the present population of this insect in clover fields of northern West Virginia, effective control of the nymphs probably would result in increased hay yields and possibly increased seed yields later in the season. This study, however, did not include any control experiments with this insect.

\section{LEAFHOPPERS}

Red clover is attacked by several species of leafhoppers, one of the most common being the potato leafhopper (Empoasca fabae Harris). The hoppers feed chiefly on the undersides of the leaves. Leafhopper injury is generally indicated by the leaf margins changing to a red or yellow color and later browning as the margin dries. A V-shaped "tipburn" is a common symptom, but is not always present. In most cases of serious injury, the plants show a lack of vigor and growth is retarded.

Rather severe infestations of leafhoppers have been observed in West Virginia, particularly in fields on dry locations. Some leaf symptoms are evident on the first hay crop, but the population does not reach a peak until later in the summer. No evidence of leafhoppers injuring the blossoms has been noted, but their general effect on the plant is undoubtedly a factor in seed production when they are abundant.

The more pubescent types of red clover are more resistant to leafhopper injury than the glabrous strains. Jewett (24) collected more adult hoppers from the non-pubescent French and Italian red clovers and found that more nymphs were present on this type, but found that no very direct correlation could be made between the amount of injury and the amount of pubescence. However, since plants having little pubescence are not common 
in West Virginia, this would not be of much importance even if a direct correlation could be made. Jewett found evidence that there may be other factors, presumably a physiological resistance, which helps reduce hopper injury.

\section{APHIDS}

Injurious infestations of aphids have not been observed on red clover in West Virginia. The greatest number appear in the spring soon after plants start new growth. Dudley and Bronson (9) have listed the pea aphid (Macrosiphum pisi Kalt.) as commonly occurring on red clover and other forage legumes. Other species, including the clover aphid (Anuraphis bakeri Cowen), also may be present in some regions.

The aphids present on clover undoubtedly cause some injury, but the numbers observed in West Virginia do not indicate that special control measures need be taken in this region.

\section{Lygus Bugs}

Extensive research has been made in recent years on the extent of damages that lygus bugs cause to alfalfa hay and seed production. Jeppson and MacLeod (22) have shown that growth of alfalfa is seriously retarded by the feeding of lygus bugs. Other studies indicated that feeding injury causes blasted buds and shriveled, worthless seed.

The extent of the damage caused to red clover in West Virginia by lygus bugs, particularly the tarnished plant bug, is not known. The adults are very abundant in clover fields during the summer months. Blasted buds that appear to be due to the feeding of these insects are common on the second or seed crop.

\section{Clover Root Borer (Hylastinus obscurus Marsh.)}

The clover root borer is one of the most injurious of clover pests. Rockwood (37) describes the insect as one of the principal factors limiting the life of a red clover stand after the first crop year. He also notes that severe infestations in the first crop year have caused large losses.

Although the root injury caused by this insect in West Virginia is far less extensive than that caused by the clover root curculio, there is still enough to justify considering it as a major pest. Roots injured by this insect are shown in Figure 2. 


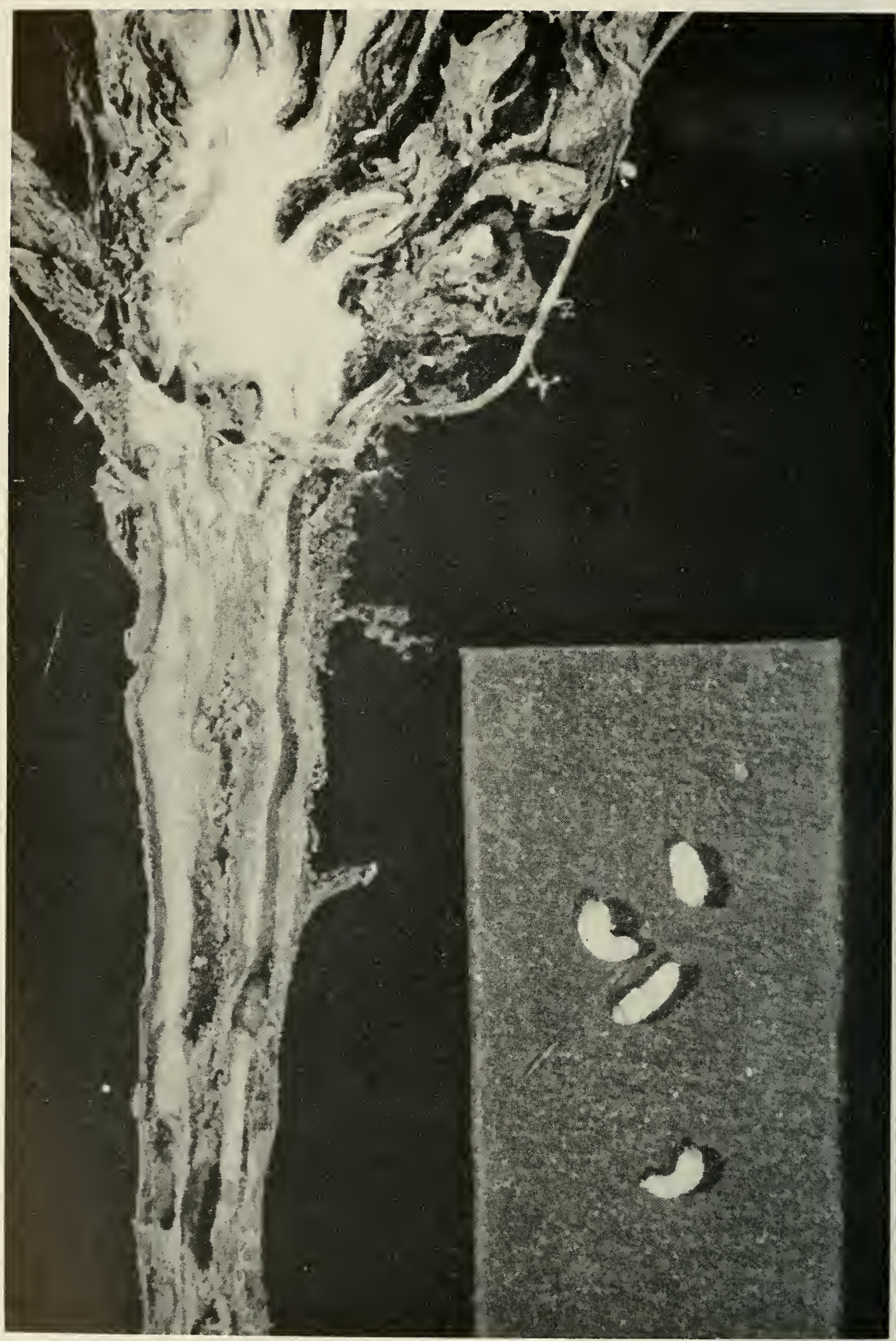

FIGURE 2. A RED CLOVER root split to show the injury caused by the clover root curculio. At the right are four larvae that were removed from the root. 
The eggs are deposited in grooves on the surface of roots or in the walls of galleries made by the female insect. After hatching, the larva begins feeding and forms tunnels which, in general, are parallel to the longitudinal axis of the root. Several larvae are generally present in the tap root. These make numerous tunnels and usually kill the plant.

Only one generation is produced each year. The insect may winter in the adult, larval, or pupal stage.

The most extensive damage caused by this insect has been observed when clover plants start to make new growth following the first hay cutting. In some instances, good stands of red clover were present until the hay crop was cut in June. With the beginning of new growth, many plants died out, and in some instances all the plants in small areas were killed. The clover root borer was found in practically every injured plant.

A root rot caused by species of Fusarium is generally associated with the root borer injury. The vascular system often is discolored far beyond the tunnels made by the root borer. Studies made at Pennsylvania State College (1) show that the clover root must be mechanically injured before the fungus can enter the plant. Fusarium spp. were found to be gaining entry in July and August following injury by the clover root borer.

\section{Clover Root Curculios}

Although the literature on these insects indicates that Sitona hispidula Fab. is the most common species, a majority of those collected in West Virginia have been identified as Sitona flavescens Marsh.

The root injury caused by the larvae points to a much greater population than is indicated by the number of adult insects collected. Adult curculios cause relatively little damage as they usually feed on the leaf margin. It is in the larval stage that this insect is most destructive. The young larvae eat the small tender roots and later attack the larger roots. Large cavities are excavated along the main roots; often these are in the form of grooves containing the feeding larva. Tap roots of red clover may show numerous scars indicating previous injuries that have healed over. The beetle winters in both the adult and egg stages. Jewett (23) reports only one generation of the insect each year.

Evidence of large populations of curculio larvae have been noted during May and June in West Virginia. The adults are not 
common until later in the summer, when they often can be observed feeding on the florets.

Several species of Fusarium have been isolated from wilted plants showing injuries on the root caused by this curculio. This would indicate that the injuries caused by the clover root curculio also will facilitate entry of root rot organisms, although they are generally superficial and not deep as in the case of the clover root borer.

\section{Clover Leaf Weevil (Hypera punctata Fab.)}

Larvae of this weevil are very common in West Virginia clover fields during spring. They have been observed in early April before any new growth was evident on the plant. After the third moult, larvae feed on the leaves during the night and drop to the ground during daylight hours. Previous to the third moult the period of feeding is reversed according to Tower and Fenton (43).

Severe defoliation may be caused by the larvae during the spring. Generally, however, the number of larvae is greatly reduced by a fungus disease. Tower and Fenton report that the fungus Empusa sphaerosperma Fres. commonly attacks the larvae and kills them rapidly. Infected larvae can be found curled on the edge of leaves since they do not drop to the ground during daylight hours. The normal green color of the larvae becomes yellow, later changing to gray as the fungus spore masses are produced on the body.

The adults also feed on clover leaves but they have seldom been observed in the fields in West Virginia. Even though their feeding usually is at night, few are believed to be present since only scattered larvae survive after epidemics of the fungus parasite.

\section{Grasshoppers}

Many species of grasshoppers are found in clover fields. The damage they cause to red clover usually is confined to leaf chewing, but occasionally they feed on the flower heads. The injury that grasshoppers cause to clover in West Virginia is important enough to warrant considering them in any insect control program.

\section{Clover Mite}

A mite, probably Bryobia praetiosa Koch., occurs commonly in West Virginia clover fields. Mites have been observed during 
the entire growing season but are generally most common during July and August. No heavy infestations have been noted except on dry locations.

Clover plants injured by mites are usually stunted; the leaves are discolored and often distorted. According to Garmen (15), spider mites are able to pierce the leaf tissues and destroy chlorophyll. Mite colonies surrounded by webby material can be observed easily on the under surface of infested leaves.

Large mite populations could seriously reduce the hay or seed yield under some conditions, but heavy infestations have not been found frequently enough to make them a major problem.

\section{Insects That Damage Only the Red Clover Seed Crop}

The injury caused by a number of other insects is restricted mainly to the flower heads and therefore has little effect on the hay yield. In areas where the second growth of medium red clover is harvested for seed, these insects are of considerable importance since they may markedly decrease the seed yield.

To estimate the damage caused by the species considered under this heading would require detailed study of each. Field observations may indicate roughly what the population is and in some cases, injury to individual flower heads can be identified. Although no attempt has been made to study each species thoroughly, enough information has been sought to give a picture of what the effect may have been on the total reduction in seed yield.

\section{Clover Tychius (Tychius picirostris Fab.)}

The most common weevil in clover fields is the clover tychius. In northern West Virginia this pinhead-size gray weevil can be collected from red clover flower heads at any time during the blooming season.

Arnott (4) reported in 1947 that Tychius picirostris was reported to be the dominant species in alsike clover and T. griseus in red clover fields. The species present in West Virginia have not been determined definitely, but are tentatively listed as T. picirostris Fab. The T. griseus of Schaeffer is listed as T. picirostris Fab. by Blatchley and Leng (6).

Arnott (4) notes that both the adults and larvae damage the seed. The larvae that hatch from eggs deposited in the pods destroy the ovules. The adults puncture the calyx and petals to reach 
the pod and developing seed on which they feed. Adults also may feed on the pollen according to Herrick and Detwiler (17). In a count, the authors found that 90 per cent of the florets were punctured, and in most of these the anthers were shrunken and discolored. In West Virginia, adults have been observed to puncture the florets at both locations and in many cases discolored anthers have been noted in florets punctured by this weevil.

The larvae are difficult to recover from flower heads. Since they feed on the developing pod and ovary, the flower must be dissected to determine if the larvae are present. From one to six larvae have been found in individual heads; however, no extensive survey of numbers of larvae present has been made.

Populations studies in West Virginia were made by counting the number of adult weevils on a given number of flower heads. Adults are found on the flower heads from the time they emerge from the sheath until the head is approaching a brown condition after blooming. Heads at the various stages of development were selected at random in making the count. Data on adult populations of Tychius picirostris and other weevils from several locations are shown in Tables 2 and 3.

\section{Lesser Clover-Leaf Weevil (Phytonomus nigrirostris Fab.)}

Another weevil that commonly causes damage to the flower heads in West Virginia is the lesser clover-leaf weevil. It is about $4 \mathrm{~mm}$. long and is iridescent green or brown. During the summer months adults usually can be found on the flower heads. The extent of injury caused by feeding adults is not known. It is the larvae that cause the most extensive damage.

The larvae are generally found in the clover heads but they also may feed in the axils of the stem. They are commonly found enclosed by the stipules of the two leaves immediately below the flower head. From that point they can easily move into the head. According to Herrick and Detwiler (17) they eat into the sheath surrounding the bud in the axil and sever the bud from the stem. When located in the flower head, the larvae feed on the base of the florets including the ovaries. The florets usually are completely severed from the head. Up to 25 per cent of the florets may be cut off or injured by one larva. Generally, only one larva has been found in a flower head.

In West Virginia the major part of the larval population is is found in the heads. Tables 2 and 3 indicate the population of 
adults and larvae in or on the heads of clover during the summer months. No attempt has been made to separate larvae of this species from those of Phytonomus meles as the two are quite similar and both are found in the flower heads.

Many larvae have been observed that have been attacked by a fungus parasite. Blatchley and Leng (6) have noted that during wet season, they are attacked by the fungus that also kills Hypera punctata.

\section{TABle 2. Survey of Clover Flower Weevils on Red Clover} Flower Heads at the West Virginia University Agronomy Farm, Morgantown

\begin{tabular}{|c|c|c|c|c|}
\hline \multirow{2}{*}{$\begin{array}{c}\text { Stage of } \\
\text { Clover Growth } \\
\text { ANd Date }\end{array}$} & \multicolumn{3}{|c|}{ No. of Adult Weevils on 100 Clover Heads } & \multirow{2}{*}{$\begin{array}{c}\text { LaRVaE of } \\
P . \quad \text { Nigrirostris } \\
\text { and P. Meles on } \\
100 \text { Clover Heads }\end{array}$} \\
\hline & $\begin{array}{l}\text { Tychius } \\
\text { Picirostris }\end{array}$ & $\begin{array}{l}\text { Phytonomus } \\
\text { Meles }\end{array}$ & $\begin{array}{l}\text { Phytonomus } \\
\text { Nigrirostris }\end{array}$ & \\
\hline $\begin{array}{l}\text { Very Early Bloom } \\
\text { (May 29) }\end{array}$ & \multirow[t]{2}{*}{65} & \multirow[t]{2}{*}{6} & 1 & 5 \\
\hline $\begin{array}{l}\text { Full Bloom } \\
\text { (June 10) }\end{array}$ & & & \multirow{2}{*}{4} & \multirow{2}{*}{27} \\
\hline $\begin{array}{l}\text { Flowering Uneven } \\
\text { 2nd Growth } \\
\text { (June 28) }\end{array}$ & 76 & 11 & & \\
\hline $\begin{array}{l}\text { Full Bloom } \\
\text { (July 11) }\end{array}$ & 44 & 1 & 11 & 14 \\
\hline $\begin{array}{l}\text { Three-fourths of } \\
\text { Heads Brown } \\
\text { (July 25) }\end{array}$ & 10 & 0 & 2 & 6 \\
\hline
\end{tabular}

\section{TABle 3. Survey of Clover Flower Weevils on Farms IN EASTERN West Virginia}

\begin{tabular}{|c|c|c|c|c|}
\hline \multirow{2}{*}{$\begin{array}{c}\text { Stage of } \\
\text { Clover } \\
\text { andowth } \\
\text { Date }\end{array}$} & \multicolumn{3}{|c|}{ No. of Adult Weevils on 100 Clover Heads } & \multirow{2}{*}{$\begin{array}{c}\text { LaRvaE OF } \\
P . \text { Nigrirostris } \\
\text { AND P. Meles on } \\
100 \text { Clover HEADS }\end{array}$} \\
\hline & $\begin{array}{l}\text { Tychius } \\
\text { Picirostris }\end{array}$ & $\begin{array}{c}\text { Phytonomus } \\
\text { Meles }\end{array}$ & $\begin{array}{l}\text { Phytonomus } \\
\text { Nigrirostris }\end{array}$ & \\
\hline $\begin{array}{l}\text { Early Bloom }{ }^{2} \\
\text { (June 1) }\end{array}$ & \multirow{4}{*}{$\begin{array}{r}140 \\
32\end{array}$} & \multirow[t]{2}{*}{17} & 1 & 26 \\
\hline $\begin{array}{l}\text { Full Bloom }{ }^{2} \\
\text { (June 13) }\end{array}$ & & & 0 & 34 \\
\hline $\begin{array}{l}\text { Early Bloom }{ }^{2} \\
\text { (July 7) }\end{array}$ & & 0 & 2 & 18 \\
\hline $\begin{array}{l}\text { Past Full Bloom² } \\
\text { (July 27) }\end{array}$ & & 0 & 3 & 10 \\
\hline
\end{tabular}




\section{Clover-Head Weevil (Phytonomus meles Fab.)}

The clover-head weevil is another common species in West Virginia. It is approximately the same size as the lesser clover-leaf weevil but its color ranges from dark brown to dark gray. Adults of this species are observed in greatest numbers during the early part of the summer, particularly early June. The greatest larval population is evident in June and early July.

Larvae of this species are similar to those of Phytonomus nigrirostris and both have very similar feeding habits. Larvae of $P$. meles apparently reach a population peak early in the summer and therefore cause less damage to the seed crop than the larvae of $P$. nigrirostris. The population of this species on clover heads is shown in Tables 2 and 3.

\section{Clover Seed-Chalcid (Bruchophagus funebris How.)}

Folsom (14) states that this chalcid was originally thought to be parasitic on the clover seed-midge, but was later found to be one of the worst of the clover pests. Most of the chalcids parasitize other insects, but this species feeds on clover seed and may reduce the seed crop materially.

The adults are about $1.8 \mathrm{~mm}$. in length and mostly shining black. In general appearance they resemble miniature wasps. Larvae taken from clover seed are white, quite plump, and footless.

Folsom (14) indicates that the female selects for ovoposition those florets in which the seeds are developing but have not yet hardened.

The larva feeds inside the seed until nothing remains but the thin outer shell. As many as three generations of this insect have been reported in one season. There are some in each generation, however, that remain in the seed until the following year.

The number of adult chalcids emerging from some seed lots indicates that this insect may be a major pest in some areas in West Virginia.

\section{Clover-Flower Midge (Dasyneura leguminicola Lintner.)}

The clover-flower midge is another insect that may reduce the amount of red clover seed produced. The adult can be easily recognized by its red abdomen. Its body length is approximately $2 \mathrm{~mm}$.

The female midge deposits eggs on the florets that are, according to Wehrle (46), on green heads about one-fourth to one-half 
open. Almost immediately after hatching. the larvae penetrate to the developing ovaries where they feed until they reach maturity. The pink or salmon-colored full-grown larvae drop to the ground from the clover head and form cocoons in which they pupate.

Eggs, larvae, and adults have been collected from several locations in northern West Virginia. At no time have the observed numbers of adults and larvae indicated that the loss of seed by injury from this insect would be excessive. Since this insect contributes to the total loss, however, better methods of control should be investigated. Several natural enemies have been noted by Wehrle (46). These may tend to keep this species in check.

\section{Insecticide Control of Insects Damaging Seed Crop}

The development of many new and effective insecticides in recent years has given new impetus to studies on methods for controlling insect pests. This has included a number of attempts to control the more severe pests of forage crops, particularly those of alfalfa and red clover.

Recent reports on the value of insecticides for increasing the yield of clover seed have included the studies of Medler and Chamberlin (30) on ladino and red clover. They found that use of DDT consistently increased the red clover seed yield whether applied as a 5 per cent dust or as a spray at one pound of actual insecticide per acre. Increased seed yields of alfalfa and clover also were reported by Pederson (34). DDT, benzene hexachloride and chlordane gave significant increases in yields, whether used alone or in combination.

Several recent reports have been made on the value of insecticides for improving the hay vield. Any beneficial effect of the insecticide on the hay crop would undoubtedly also affect the yield of seed from the following cutting. This is particularly true of insects such as the clover root borer which may kill many of the plants during the growing season. Marshall et al. (29) found that benzene hexachloride applied to fields during the flight of clover root borers in the spring gave fairly effective control. They also reported that this material did not reduce the palatability of the hay to livestock. Weaver (45) has recently reported that benzene hexachloride also effectively controls the meadow spittlebug nymphs when applied early in the spring.

Studies by Schwardt et al. (39) indicated that DDT and benzene hexachloride would control a number of insect pests of red 
clover and increase the hay yield. A reduction in the insect population was most apparent in the case of the weevil Hypera meles, and the meadow spittlebug.

Many factors must be considered in addition to the increase in hay and seed yield when insecticides are used on forage crops. Hazard due to insecticide residues has been a major problem. Residues carried on the harvested hay may have a deleterious affect when fed to livestock. This has become increasingly evident as the harmful effects of certain insecticides such as DDT have been reported.

The straw residue remaining after clover is harvested for seed is generally discarded, therefore insecticides applied to increase the seed yield need not be considered as a potential danger to livestock. Insecticides applied to the seed crop do, however, present a problem of another type. Since bees are required to pollinate red clover and are present in the fields once the plants have come into bloom, any application of insecticides after that period might severly reduce the seed set. Control of many of the insects that reduce the quantity of seed and are most active and abundant in fields during the flowering period appears to be impossible without also reducing the bee population. Linsley and MacSwain (28) have reported that DDT applied to flowering alfalfa for lygus-bug control reduces the bee population by killing or, possibly, keeps bees from the fields by some sort of repellent action. It appears that some control of insects that reduce the seed set may be obtained by applying the material before the plants flower.

Some preliminary tests have been made in West Virginia to find to what extent use of insecticides would increase red clover seed yields. The materials were applied between the time when the hay was removed and the period when flowers were again visible in the fields. No applications were made at blossom time in order to avoid injury to bees.

\section{EXPERIMENTS}

Test plots were located on eight farms in the four eastern counties that make up the main clover seed-producing area in West Virginia.

Three insecticides were applied to the seed crop in dust form as follows: 5 per cent DDT at the rate of 40 pounds per acre, 5 per cent DDT at the rate of 20 pounds per acre, 15 per cent sabadilla 
at 40 pounds per acre, and 5 per cent methoxychlor at 40 pounds per acre. Each material or rate of application was replicated three times, which, with check plots, made a total of 15 plots at each location. The 20 by 20 -foot plots were randomized in a rectangular area located in a section of the field that seemed to have the most uniform stand.

Dusts were app:ied with a hand duster. Two applications were made, the first soon after new growth had started following the hay crop harvest, and the second at approximately the time that the first flowers were showing color.

Sample areas, 5 by 10 feet, were harvested from each plot just preceding the time that the entire field was cut. The samples were then dried in a drying house. Seed was threshed from the straw by running it first through a hammer mill and then through a screening mill that separated the seed from other material. One objection to this method of threshing was that the hammer mill tended to break some of the seeds. This, however, did not materially affect the weight of the yield.

The plot yields at six locations are shown in Table 4. Plots at two locations were not harvested due to the very uneven stand that was apparent at harvest time. Plots at three other locations were harvested but had poor and uneven stands and were not considered to be of much vaiue. These were located at the Ours and Lambert farms and at the Reymann Memorial Farms and are included in Table 4.

Much difficulty was encountered after hay harvest in selecting areas for plots that would produce an even stand at the time of seed harvest. The clover stand in areas that appeared to be rather uniform at the time the hay was harvested was often uneven when the seed crop was cut, even though no extensive loss of plants was evident during the intervening period.

Results shown in Table 4 seem to indicate that the seed yield was increased by the application of insecticides. However, analysis of the data secured from the six farms revealed that a significant increase was obtained at only one farm. The variation in seed yield between plots treated with the same material was usually correlated with the thickness of the stand before harvest. For this reason, it is believed that a yield calculated on a plant or flowerhead basis would be more accurate than that calculated on an area basis. 


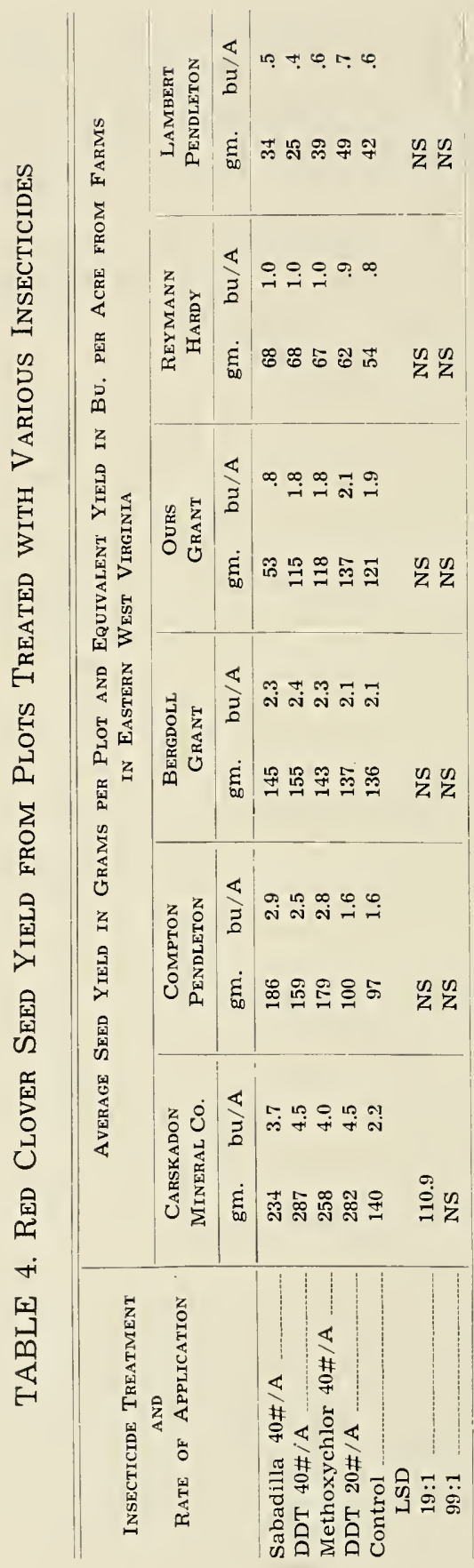




\section{EXPERIMENTS}

An insecticide trial similar to those in 1948 was conducted on the Carskadon Farm in Mineral County in 1949. DDT and methoxychlor were used in 5 per cent dust form. Eight replications of each treatment were randomised in a rectangular area. Very wet weather throughout the period of growth of the seed crop caused an epiphytotic of the blackpatch disease of clover at that location and interfered with the timely application of the dusts. When it was found that blackpatch also caused an extensive reduction in the seed yield, no attempt was made to determine the effect of the insecticide.

\section{EXPERIMENTS}

Combinations of an insecticide and fungicides were used on plots on the Carskadon Farm in 1950. The combination was used in an effort to control the blackpatch disease in addition to the insects. A dry period occurred during the growth of the seed crop. This effectively checked the development of blackpatch so that there was no increase in yield due to the application of the fungicides.

Five per cent methoxychlor dust was used in combination with three fungicides. Two applications were made at periods closely approximating those described under 1948 experiments. Two later applications were made of the fungicides after the plants had commenced to flower. The seed yield obtained from two hundred clover heads harvested from each plot is given in Table 5. The uniform yields obtained from treated and nontreated plots indicate that the methoxychlor did not increase the amount of seed as it had in the 1948 experimental plots on the same farm. Weather conditions in the 1948 and 1950 gruwing seasons were quite different. This may have had some effect on the insect population, though no difference was obvious.

\section{DISEASES}

The damage caused to the clover hay and seed crop by diseases may equal or be greater than that caused by insect pests. Many of the fungus diseases are confined to the foliage and are of major importance only from the standpoint of hay production. The foliage diseases will, however, tend to reduce the amount of seed harvested from the seed crop by their combined effect on plant vigor. In addition to the foliage diseases, several other fungus diseases 
TABle 5. Red Clover Seed Yield from Plots Treated with FUnGICIDES AND INSECTICIDES

\begin{tabular}{|c|c|c|c|c|c|c|}
\hline \multirow[t]{2}{*}{ TREATMENTS } & \multicolumn{5}{|c|}{$\begin{array}{c}\text { Plot Replications } \\
\text { Weight OF SEEd From } 200 \text { Heads } \\
\text { IN GRAMS }\end{array}$} & \multirow[t]{2}{*}{ Average Yield } \\
\hline & 1 & 2 & 3 & 4 & 5 & \\
\hline $5 \%$ Methoxychlor & 23.5 & 28.0 & 23.0 & 29.5 & 26.5 & 26.1 \\
\hline $\begin{array}{l}5 \% \text { Methoxychlor } \\
\text { and } 1 \% \text { Bioquin } 1\end{array}$ & 24.5 & 26.0 & 25.5 & 26.0 & 26.0 & 25.6 \\
\hline $\begin{array}{l}5 \% \text { Methoxychlor } \\
\text { and } 4 \% \text { Fermate }\end{array}$ & 21.0 & 23.5 & 24.5 & 29.5 & 26.5 & 25.0 \\
\hline $\begin{array}{l}5 \% \text { Methoxychlor and } 5 \% \\
\text { Crag Turf Fungicide }\end{array}$ & 29.5 & 26.5 & 23.5 & 29.5 & 22.0 & 26.2 \\
\hline No Treatment & 25.0 & 26.0 & 25.5 & 26.0 & $\ldots$ & 25.6 \\
\hline
\end{tabular}

may directly affect the quantity of seed produced. Included in this group are northern anthracnose and southern anthracnose. The blackpatch disease, previously thought to be a foliage disease of minor importance (40), has been found to attack the stems and the blossom heads and to reduce the seed yield severely. Only two diseases have proved to be major factors in the thinning of clover stands; they are crown rot (Sclerotinia trifoliorum Erikss.) and a root rot caused by species of Fusarium. A number of other fungi have been responsible for killing many plants during the seedling stage, but are not known to cause death of mature plants.

Much difficulty has been experienced in evaluating the amount of injury caused under field conditions by individual diseases. This has been particularly true of those generally limited to the foliage. Clover plants in the field usually are host to several diseases just as they are subject to attack by several insect pests. Thus any stunting or other unusual condition that can be observed may be the composite result of the injury caused by insects and that caused by diseases.

\section{Diseases that Cause the Death of Mature Plants}

The two diseases (crown rot and root rot), previously mentioned as causing the death of plants and the resulting thin stands, can be considered among the most important causes of clover failure in West Virginia. 
Crown Rot (Sclerotinia trifoliorum Erikss.)

Crown rot or stem rot is one of the most destructive diseases of red clover and other forage legumes. The disease appears to be widespread in the northern part of the state even though many fields have been found in which it apparently did not occur.

Gilbert and Myer (16) described this disease as a major cause of "clover sickness" in Kentucky in 1915. More recent reports have indicated that it is a primary factor throughout the southern clover belt.

Crown rot is most destructive during the late winter and early spring months. Visual symptoms can be noted then on plants that have been infected during the late fall or winter months. The disease is less likely to appear in patches in red clover stands than in alfalfa; generally, scattered plants over the entire area become infected and die. The entire crown region is invaded by the fungus under favorable conditions. This kills the plant. A

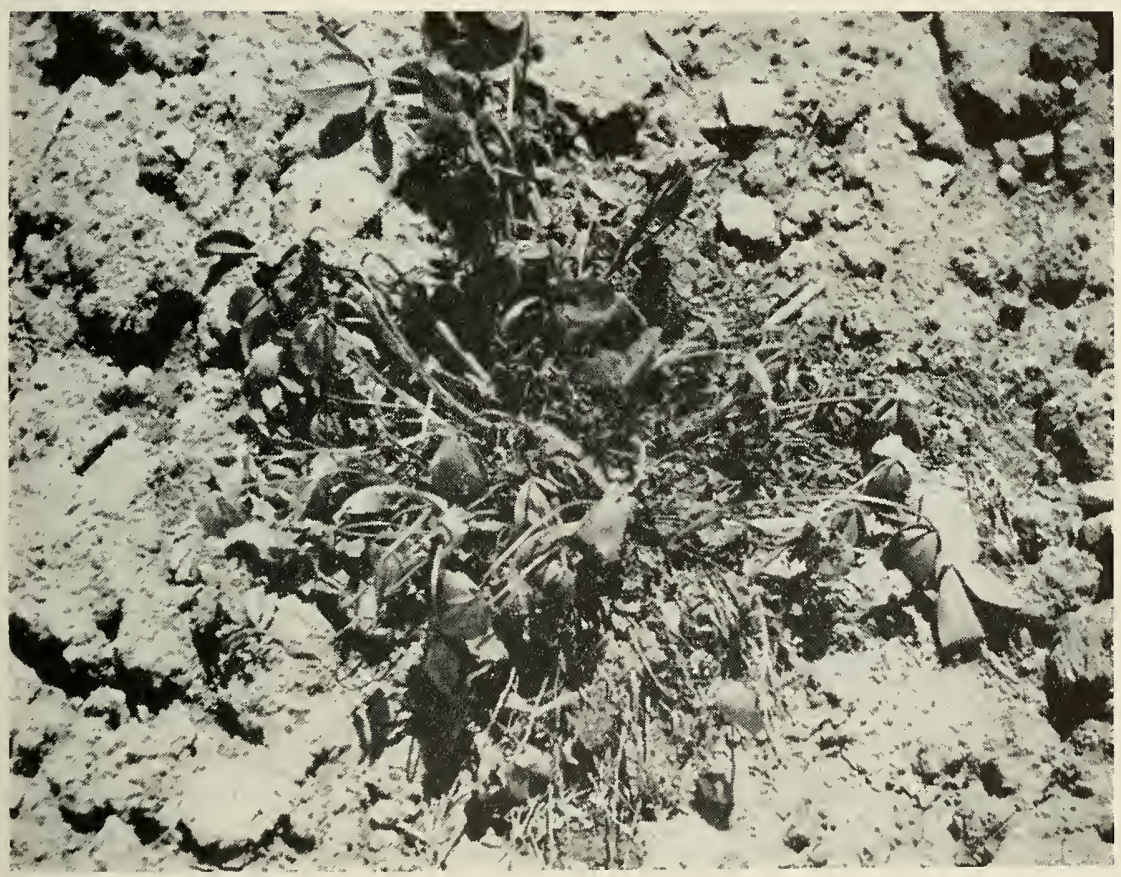

FIGURE 3. SINGLE PLANT of red clover affected with crown rot. Note drooping leaves; disease kills entire plant. Much of damage caused by crown rot occurs during mild winter weather, often is confused with winter injury. Crown rot is one of principal causes of reduced stands in the second-year crop. (Photograph by courtesy of Division of Forage Crops and Diseases, USDA.) 
fluffy white mycelium often is evident on the surface of infected parts. Hard, black sclerotia are usually found in the plant tissue or in the surrounding soil after the death of the plant. The development of crown rot is stopped by warm spring days; however, periods of cool, wet weather later in the spring may result in a further loss of plants.

The thinning of clover stands by crown rot would cause a reduction in hay and seed yields later in the season. Continued mild winters in the mountain region would undoubtedly favor the spread and destructiveness of this disease. Red clover strains that are resistant to crown rot appear to be the logical means of control. Valleau et al. (44) reported that red clover adapted to Central Kentucky conditions was less injured by crown rot than other American and European varieties.

\section{Fusarium Root Rot}

Recent reports have indicated the major role root rots play in clover failures. Kilpatrick and Hanson (26) have found that root rots, crown rots, and wilt rank among the most important diseases of red clover in Wisconsin. Several species of Fusarium were found to be associated in the complex. These included $F$. oxysporum Schl., F. solani (Martius) App. and Wr., F. moniliforme Sheld., and $F$. roseum $L k$. Kreitlow and Hanson (27) also have reported isolating $F$. oxysporum and $F$. solani from diseased red clover plants in Pennsylvania. They found that these fungi enter the host plants through wounds in the crown and the tap root and are responsible for a severe thinning of plants during the second year. An earlier report from Pennsylvania (1) indicates that the fungus parasite may enter the host after it has been injured by the clover root borer.

It has been found that Fusarium root rot is very common in West Virginia and that it is a major factor in the thinning of clover stands, particularly during the second year. These fungi also kill some seedling plants during the first year. Infected plants have several symptoms; the top growth may be stunted or wilted and the leaflets of large piants often show yellow or red discoloration of the margins. At least a part of the vascular system of the tap root is dark in color. Sections of tap roots indicate that the discoloration is most evident at the point where the root has been injured by some insect or other agent. It has been noted previously (section on insect pests) that this disease is generally associated 
with injuries to the root system caused by the clover curculio or by the clover root borer.

Fungi isolated from a large number of wilted seedling red clover plants proved to be species of Fusarium in all except a few cases. Clover that had been seeded in late June or early July in a corn field (a two-year crop rotation test) was found to have scattered wilted plants at about the time that the seedlings had reached a three- or four-leaf size. Evidence of injury to the root system by clover curculio larvae was found in many cases of wilted plants.

Effective control of this disease would depend on the control of insects that feed on the root system of the plant. Field observations have indicated that both hay and seed yield would be substantially incrcased by controlling this insect and disease association.

\section{Diseases that Ordinarily Do not Kill the Plant}

Included in this group of diseases are those that under special conditions might cause the death of red clover but usually do not. These diseases often affect the quantity of seed produced, but they are considered to be of more importance in the production of hay.

\section{Black Stem (Phoma trifolii Johnson and Valleau)}

Black stem occurs very commonly in West Virginia red clover fields. It is most prevalent on the hay crop, but may be equally severe on the second, or seed crop, during rainy seasons. The severity of the disease appears to be correlated with the density of the clover stand. Black stem is seldom very injurious in thin stands, but may be in the heavier stands.

The most commonly observed symptom is the blackening of the stems, but this injury probably has less effect on the plant than that due to loss of leaves. When the disease is severe, leaf infections result in extensive defoliation of the lower parts. Johnson and Valleau (25) have listed black stem as a major factor responsible for clover failure in Kentucky. They report that it is particularly destructive in fields planted with unadapted clover strains, and that it appeared to kill some plants.

Black stem was abundant in fields during most of the growing seasons of 1948 and 1949. It was far less extensive in the seedproducing region during the relatively dry season of 1950. This 
disease has no direct effect on seed production other than that caused by reduced stands and less vigorous plants.

Stemphylum Leaf Spot (Stemphylium sarcinaeforme Wiltshire)

Stemphylium leaf spot is quite common on red clover throughout the State. Leaf infections gradually enlarge and eventually destroy the entire leaf. Many of the lower leaves often are destroyed, particularly in thick stands. The lesions on leaves are typically irregular with concentric zones of brown spots of various sizes.

The relation of this species of Stemphylium to other similar species occurring on red clover and other legumes has been discussed by Smith (41). A majority of the collections made in West Virginia have been identified as Stemphylium sarcinaeforme.

The disease is most injurious to the hay crop in that it reduces the quality because of the loss of lower leaves. Infections can be found on most plants during the entire growing season, but it appears to be most injurious in early summer.

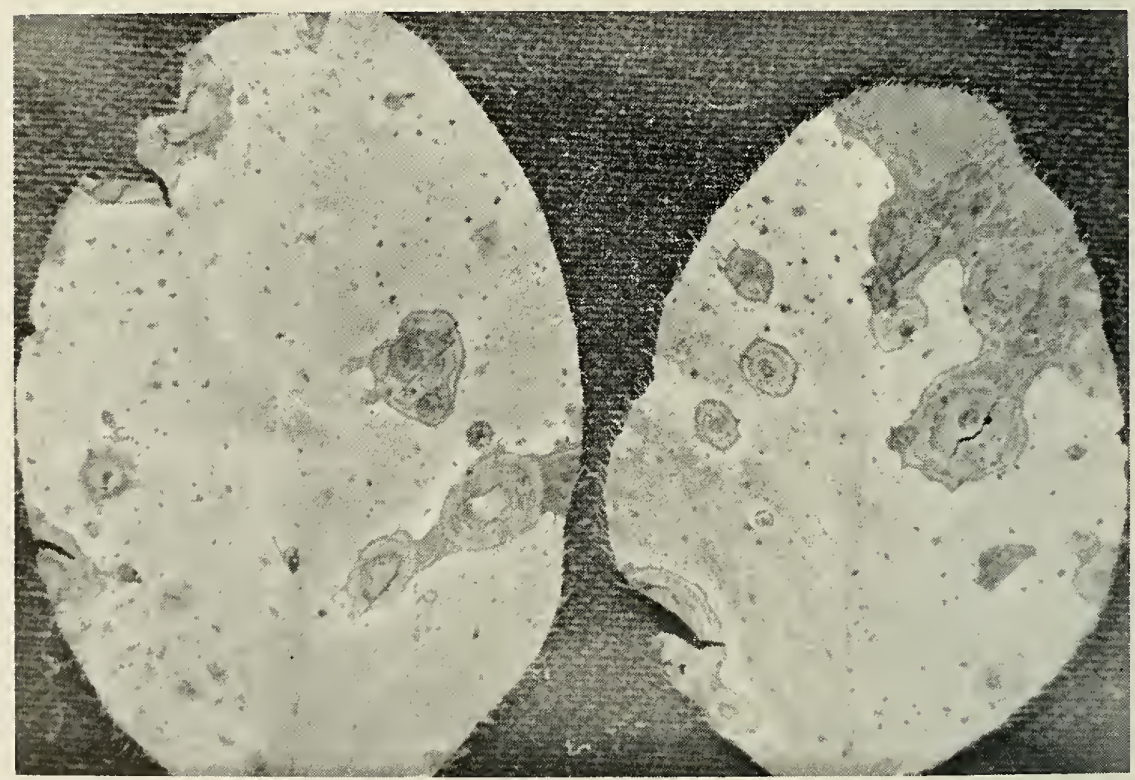

FIGURE 4. RED CLOVER leaves afiected with Stemphylium leaf spot, most prevalent leaf disease on red clover in West Virginia. It often causes much loss in yield and quality of the hay crop and may indirectly influence seed yields. (Photograph by courtesy of Division of Forage Crops and Diseases, USDA.) 
Powdery Mildew Erysiphe polygoni D. C.

Powdery mildew infections on red clover usually are evident throughout the growing season. The disease is favored by cool, dry weather and usually is most severe during the late summer and fall. Fields of clover may appear silvery gray in the fall due to the superficial growth of mycelium and conidia on the leaves. The leaves often are yellow or brown when heavily infected.

The seed yield would undoubtedly be reduced when epiphytotics of this disease occur during the time that the seed crop is maturing. Heavily infected plants appear to be stunted and produce smaller flower heads. The main hay crop generally escapes injury since it is cut in June before powdery mildew develops to any extent.

Red clover plants having varying degrees of resistance to at least one race of powdery mildew have been grown in the greenhouse from seed produced in eastern West Virginia. Some of the plants appeared to be completely resistant to the disease. It is believed that such plants would be a valuable source of breeding material, particularly since the improved variety, Wisconsin Mildew Resistant, has not withstood the winter conditions occurring in this region.

Pseudopeziza Leaf Spot Pseudopeziza trifolii (Biv. Bern.) Fckl.

Pseudopeziza leaf spot is a foliage disease occurring commonly in northern West Virginia. The infections seldom are severe enough to cause defoliation, but this has been observed in a few instances. The spot infections are restricted in size and generally do not coalesce. This disease, although abundant, is not believed to be a major factor in either hay or seed production.

Northern Anthracnose Kabatiella caulivora (Kirch.) Kavak. and Southern Anthracnose Colletotrichum trifolii Bain and Essary

At no time in the three years of this study was either northern or southern anthracnose a limiting factor in hay or seed production. Northern anthracnose has been observed at two locations in the mountain region but did not cause extensive damage. Weather conditions were believed to be ideal for the occurrence of these diseases in the eastern region during the summers of 1948 and 1949 but none was observed. The reason for the absence of either in that region has not been evident. Injury caused by northern anthracnose is shown in Figures 5 and 6. 

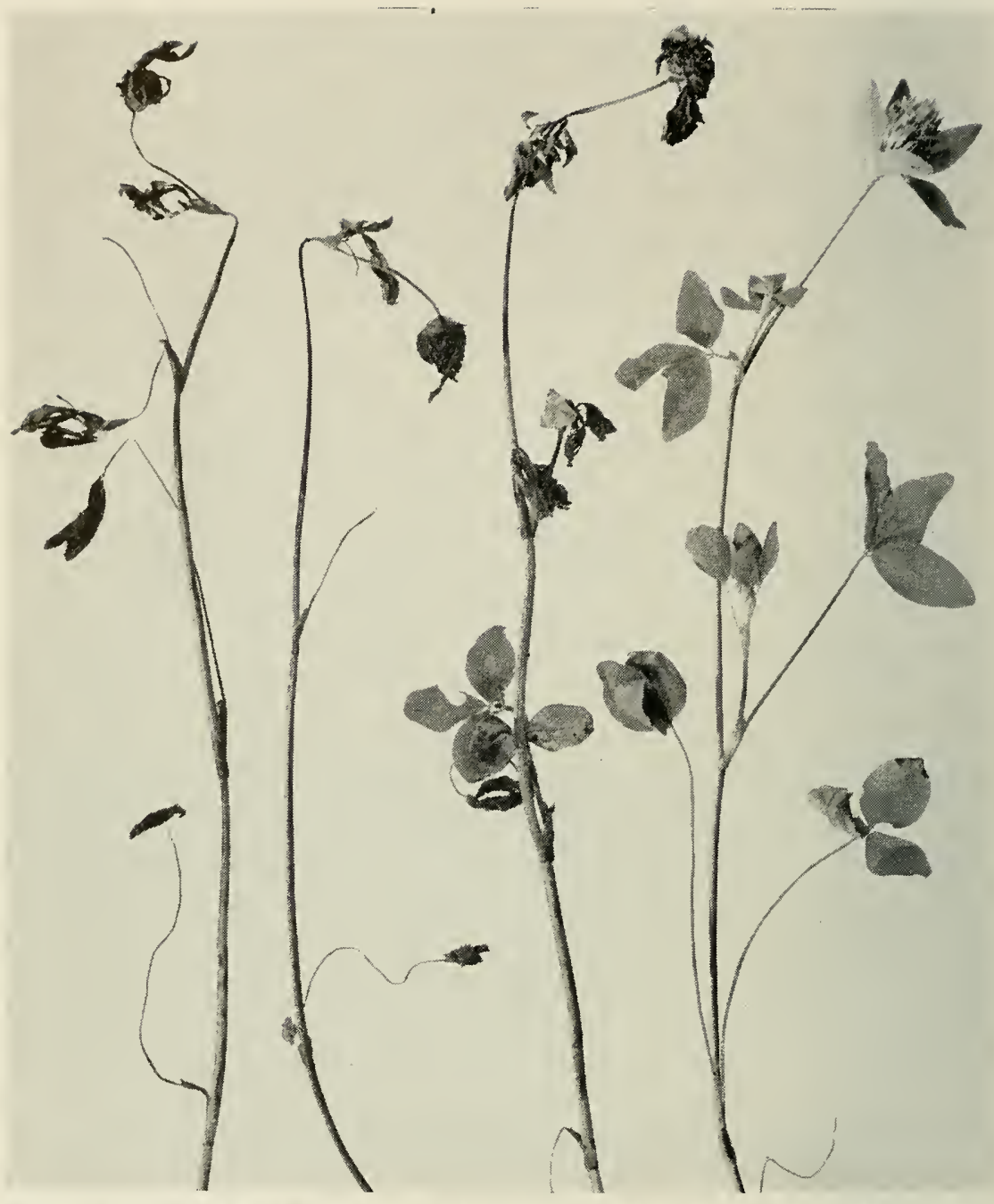

FIGURE 5. THREE PLANTS injured by northern anthracnose and healthy plant.

Soотy Bцотсн Cymadothea trifolii (Fr.) Wolf.

Sooty blotch is another common disease that does little damage to red clover. Alsike clover may practically be defoliated by this disease and it also is quite common on white clover. It has appeared in several instances that red clover is more heavily infected when alsike clover has been included in the meadow seed mixture. The alsike clover present undoubtedly serves as a source of abundant inoculum for the red clover. 

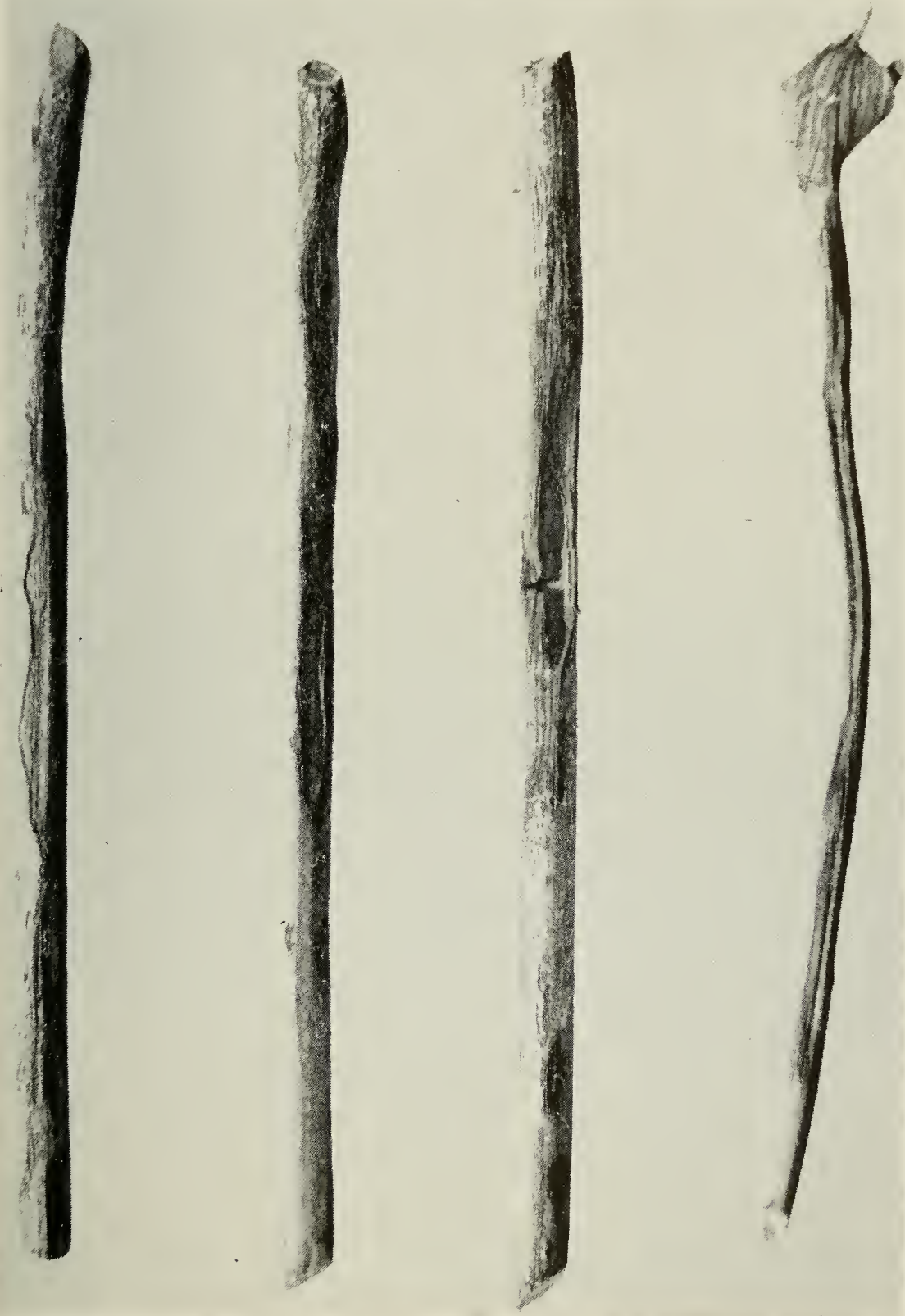

FIGURE 6. SECTIONS of clover stems showing nature of injury northern anthracnose causes. 
Most of the lesions develop on the underside of the leaflets, in some instances being so thick that the surface appears black. Conidia of the Polythrincium stage are produced on the lesions and serve as inoculum for further spread of the disease.

Although sooty blotch is quite common in West Virginia, it seldom becomes severe enough to have more than a minor effect on red clover hay or seed production. Sooty blotch causes much greater defoliation on alsike clover plants than on red clover. It is believed that this disease would cause severe damage in meadows having a large proportion of alsike clover seed in the mixture.

\section{Rust Uromyces trifolii fallens (Desm.) Arth.}

Clover rust may be found on the leaves from midsummer until cold weather. The reddish-brown uredial pustules on the under surface of the leaves are the ones most commonly observed. These are followed by the telia at the same point or separately. The yellow aecial stage may occur on the leaves, or may also be found on stems and petioles.

It has been noted that this rust causes little injury to the red clover hay and seed crops in West Virginia as it seldom becomes widespread until after both crops have been harvested. Heavy rust infections would tend to reduce the vigor of the plant just before the winter weather, at a time when the plant should be in the best condition.

\section{Virus Diseases}

A complex of virus diseases that are transmitted by aphids and leaf hoppers occurs on many legumes. A number of these appear on red clover in West Virginia. No attempt has been made in this work to determine the viruses or the agency that transmits them. Field observations indicate that red clover virus diseases are widespread and may cause extensive damage in some areas.

Symptoms similar to those described by Osborn (33) for red clover vein mosaic are quite common. This virus, which is transmitted by the pea aphid, Macrosiphum pisi (Kltb.), causes a yellow discoloration along the veins and little stunting. Leaf mottling, dwarfing, and vein yellowing are the common symptoms observed. It also has been noted that infected plants produce stunted, and often few, flower heads. Infected plants become most noticeable when the new growth is beginning after the hay has been harvested in June. The dwarfing or stunting undoubtedly would cause reduction in hay or seed yield. 


\section{Blackpatch}

The blackpatch disease of red clover and other legumes has been found in this study to be one of the major factors limiting red clover seed production in eastern West Virginia. Because very little is known about this disease it was made the subject of a special study.

Blackpatch was reported from Kentucky (2) in 1933 as a previously undescribed disease of clovers and other legumes. The casual fungus was described as one that grows over the surface of the leaves, penetrating here and there to produce large, black lesions. The name blackpatch was suggested because of the similarity of its growth habit to that of brownpatch of grasses (Figure 7). Other reports of this disease in eastern United States have appeared at intervals, but none of these reports have considered it of major importance.

Smith (40) found the disease on red and white clover in Wisconsin and stated that the lesions were limited to the leaf-blade tissue. Inoculations failed to produce infections on any other part of red or white clover plants. Chilton (7) isolated the blackpatch fungus from two out of over 28,000 surface disinfected red clover seeds. He noted that the disease might be carried into new fields in the seed since no spores were known. Weimer (47) recently reported blackpatch to occur on a number of forage legumes in Georgia.

The taxonomic position of the blackpatch fungus has not been determined. The present study substantiates reports that the fungus produced no spores in culture or on the host. The disease it causes, however, is much more destructive than earlier reports have indicated.

\section{Characteristics of the Blackpatch Fungus}

Smith (40) describes the fungus isolated in Wisconsin as follows: "In culture, the mycelium is hyaline when young but soon becomes dark green and finally dark brown or black with age. It is composed of large, branching septate filaments filled with granlar protoplasm, but with numerous vacuoles in the older portions. Cells of the larger filaments average about 16 microns in width although many of them are short and round, having a diameter of 28 to 30 microns. In shape, these short cells appear much like chlamydospores, but their walls are not thickened and the 
cell contents do not appear different from those of other cells of the mycelium. In some instances the fungus produces numerous clusters of short cells in the media, which resemble conidia in grape-like clusters." The blackpatch fungus isolated from red clover in West Virginia fits this description in every detail.

In culture on malt extract agar, the fungus grew more rapidly at temperatures of $28.5^{\circ} \mathrm{C}$. and $21^{\circ} \mathrm{C}$. than at any higher or lower temperatures. Smith reported that the greatest average width of colonies was produced at $24^{\circ} \mathrm{C}$. and $28^{\circ} \mathrm{C}$.

The blackpatch fungus has been reported to be pathogenic on several legumes. A number of species were inoculated by Smith and the following were Iound to be susceptible: red clover (Trifolium pratense L.), white clover ( $T$. repens L.), ladino clover (T. repens giganteum Lagr. Foss), crimson clover (T. incarnatum L.), alsike clover ( $T$. hybridum L.), white sweetclover (Melilotus alba Desr.), yellow sweetclover (M. officinalis Lam.), sourclover (M. indica All.), and alfalfa (Medicago sativa L.). Weimer (47) has reported blackpatch to be pathogenic on soybean (Glycine max [L.] Piper), cowpea (Vigna sinensis [Torner] Hassk.), kudzu (Pueraria thunbergiana Benth.), and blue lupine (Lupinus augustifolius L.).

In addition to red clover, the disease has been observed in eastern West Virginia on alsike clover, white clover, alfalfa, black medick (Medicago lupulina L.), and Korean lespedeza (Lespedeza stipulacea Maxim.). It has been noted that blackpatch usually occurs on species other than red clover only when red clover is near. The disease is common on other species when they are seeded in a mixture that includes red clover.

Effect of Weather Conditions on the Disease in Eastern West VIRGINIA

Blackpatch was first noted on red clover in West Virginia in early August, 1948. The typical black patches began to appear in first-year clover fields during a period of wet weather (Figure 7). As the season advanced and the wet weather continued, the fungus spread rapidly until few plants in some fields were free from the disease. The disease was not observed on the second-year seed crop in 1948, although later observations indicated that it must have been present in considerable amounts but was not recognized.

Abnormally high rainfall occurred again in eastern West Virginia during most of the 1949 growing season. Several extended 


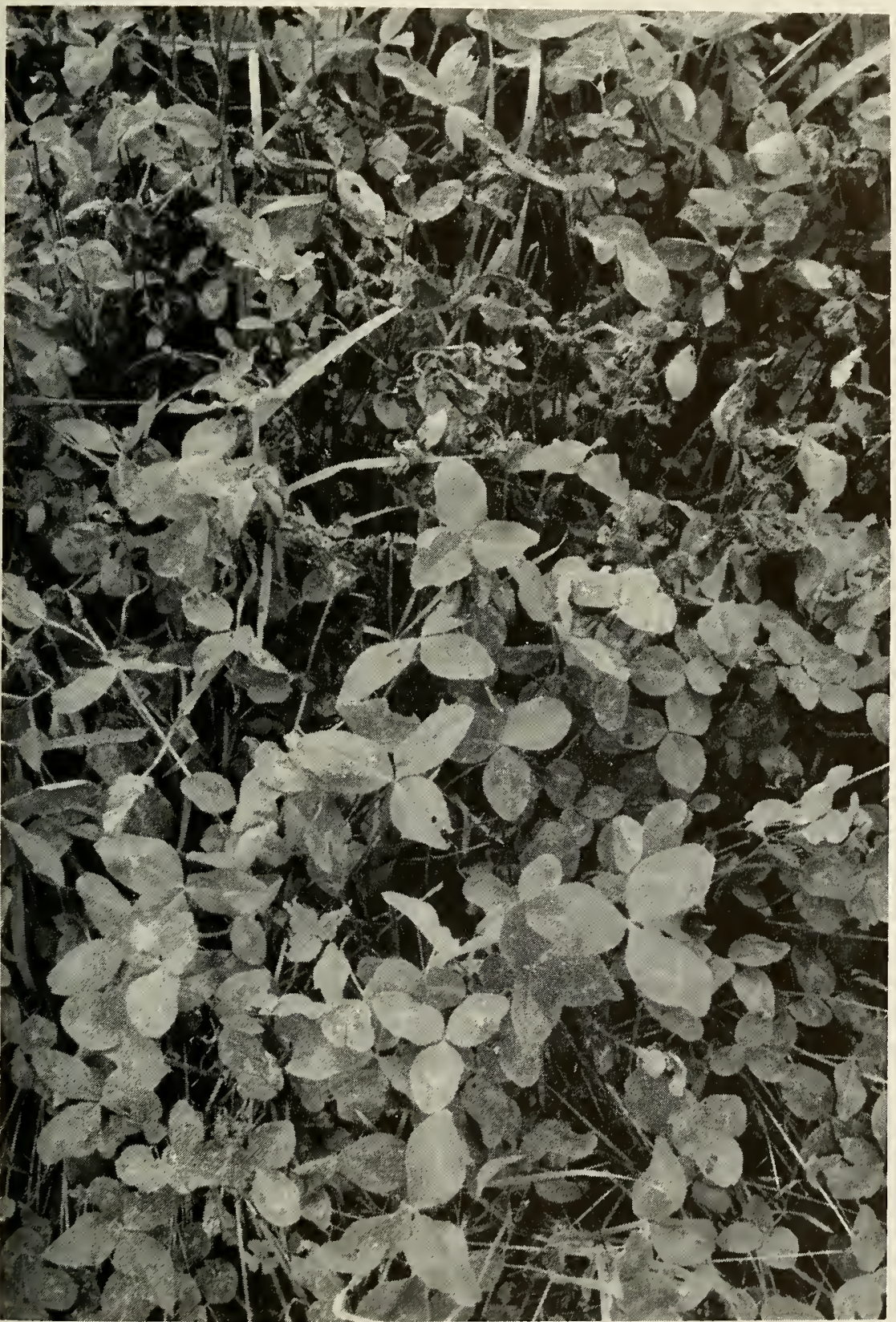

FIGURE 7. SMALL AREA of blackpatch infection in first-year red clover. Evidence indicates such patches arise from an infected seed; the fungus spreading by aerial mycelium from infected seedling to adjacent healthy plants. 
periods of heavy rainfall and high humidity during July and August were ideally suited for the growth and spread of the blackpatch fungus. Blackpatch was again noted in the first-year red clover fields where it spread rapidly. The disease also was found in the seed-crop clover that was only at the early bloom stage when general infection was first observed. Some seed fields had the appearance of ripening prematurely as a result of the killing of various plant parts by the fungus.

The 1950 growing season was relatively dry compared with the two previous years. Blackpatch was found in both first- and secondyear clover fields, but only a small proportion of the plants were severely infected. In addition, the disease was localized in small areas and was restricted for the most part to the leaflets or leaves near the ground. The weather conditions during the 1950 season were not favorable for the rapid spread of the fungus from plant to plant or into the higher parts of infected plants.

In a survey of the northern part of West Virginia, the disease was not found west of the Allegheny Front. Blackpatch is found in most of the clover fields, particularly those in the valleys to the east of the mountain plateau. The disease may not have reached the mountain areas or may be restricted to the lower valleys to the east by climatic conditions.

\section{Plant Parts Affected}

Previous descriptions of this disease and the experiments of Smith (40) indicated that the leaves and petioles were the only parts of the clover plant subject to attack and that the disease caused relatively little damage. The present study has shown that the stems and flower parts of red clover also are subject to infections that may result in severe plant injury and in striking reductions in the seed yield.

In the field, the leaves appear to be more susceptible to infection than other parts, and the disease is first observed on the leaves near the base of the plant. New growth is definitely more susceptible to infection than older growth. Even if the weather is not favorable for extensive growth of the fungus, it often can be found on the new leaves being produced at the crown of the plant. The fungus spreads from leaf to leaf and from one plant to another by means of the aerial mycelium that, during growth, forms a web over the infected parts. Since the leaves of an individual plant are in contact with and overlap those growing around it, the fungus can make rapid growth from plant to plant 
when conditions are favorable. Smith (40) has described the growth of the mycelium over the leaf surface and the pathological histology of the disease on the leaf tissue.

The stems of infected plants often are enclosed in a sheath of the aerial mycelim (Figures 8 and 10). The mycelium may penetrate into the stem to cause lesions similar in appearance to those formed on the leaf. In some cases, little aerial mycelium is present on the surface of the stem and concentric rings may appear in the lesions as in Figure 9. As in the case of the leaves, younger parts of the stem are more susceptible to infection than older parts. The section of the stem just below the flower head is the point most frequently injured in the field. Infection here usually results in the stem bending or breaking and no further development of the flower head.

Under favorable conditions the fungus spreads to all aboveground parts of the clover plants including the flower heads. The effect of the disease on seed yield is influenced markedly by the stage of development of the flower head when the fungus reaches it. If the flower head is in the pre-bloom to full-bloom stage, the fungus may invade and kill all parts including the ovaries so that no seeds are produced. If the flower parts are attacked after the seed coat has started to harden, some viable seeds may be produced. The more mature the seed is at the time the flower head is invaded by the fungus, the greater the yield of viable seed will be.

Flower parts are attacked by the aerial mycelium in the same way that it attacks the leaf. The mycelium radiates out in all directions within the tissue from the point where the aerial mycelium penetrates the surface. A weft of dark, aerial mycelium often covers the flower head. This makes it easy to identify infected heads (Figures 8 and 11).

In the laboratory, red clover stems and flowers were inoculated with fragments of the fungus mycelium and held under optimum conditions of temperature and humidity for the growth of the fungus. Lesions appeared at many of the inoculated points in three or four days. The age of the tissue influenced infection. Young tissue was much more susceptible than aged tissue.

Since the fungus produces no spores, its means of reaching the higher parts of the plant where the flowers are produced has been studied. In many instances the aerial mycelium can be traced from leaf infections near the crown of the plant, along the stem to the flower heads. In other cases, however, the diseased area 


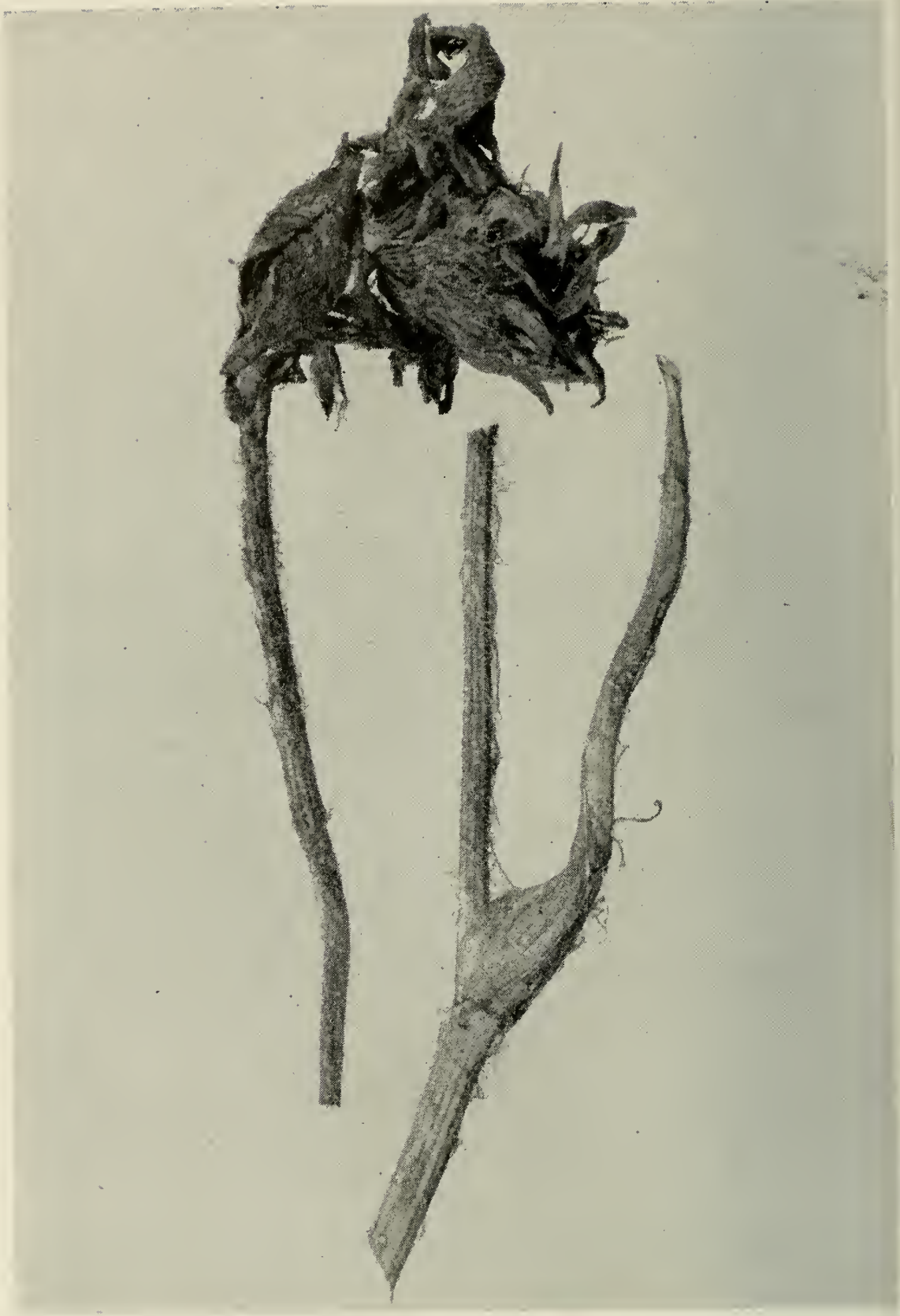

FIGURE 8. A STEM SECTION and a flower head overgrown by the blackpatch fungus. Such infected heads may be killed before seeds are formed or before they mature, in which case the seeds are likely to be infected by the fungus. 


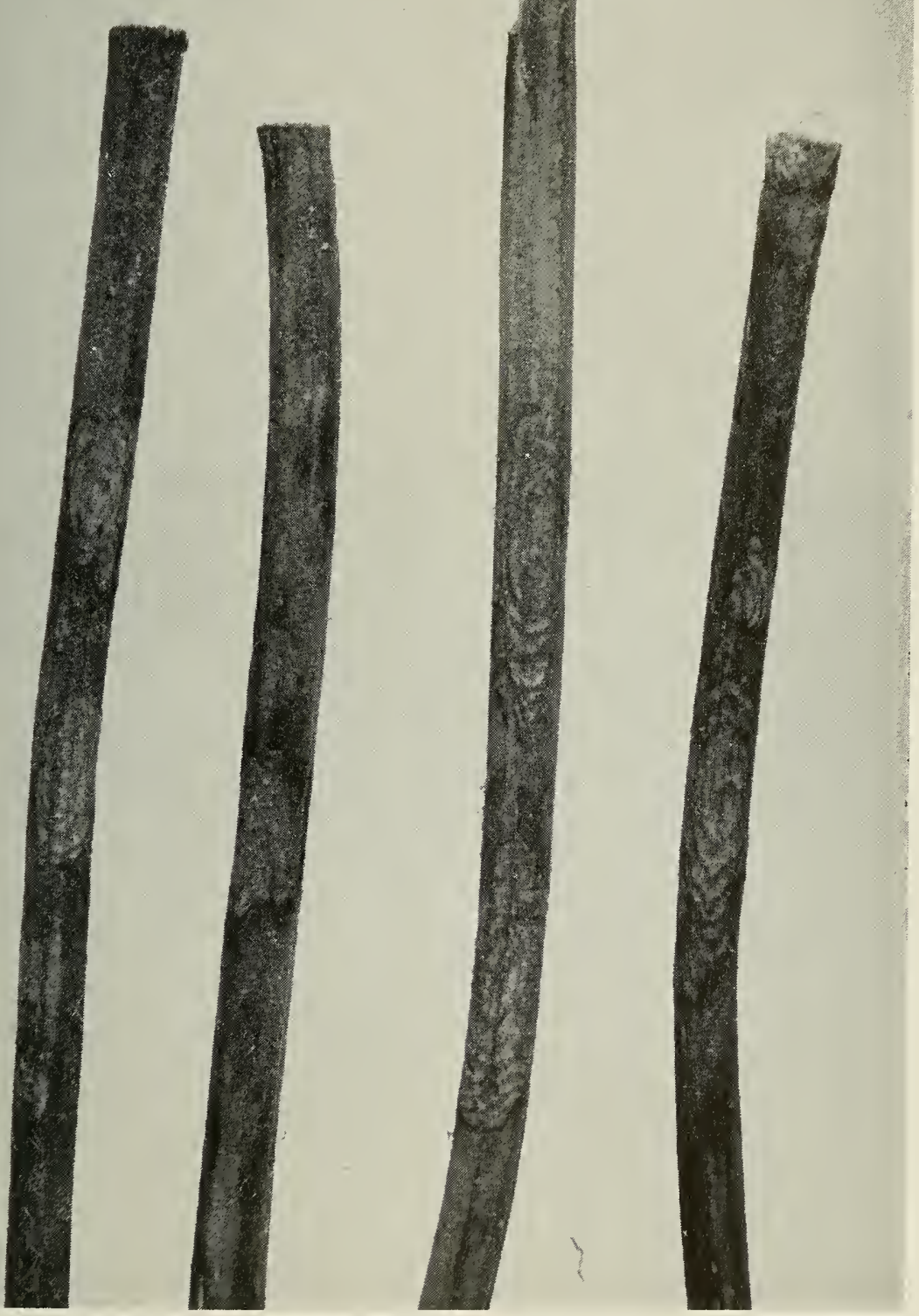

FIGURE 9. CLOVER STEMS showing cankers caused by blackpatch fungus. Such girdled stems may result in reduced seed yields even though the fungus may not reach the blossom. 


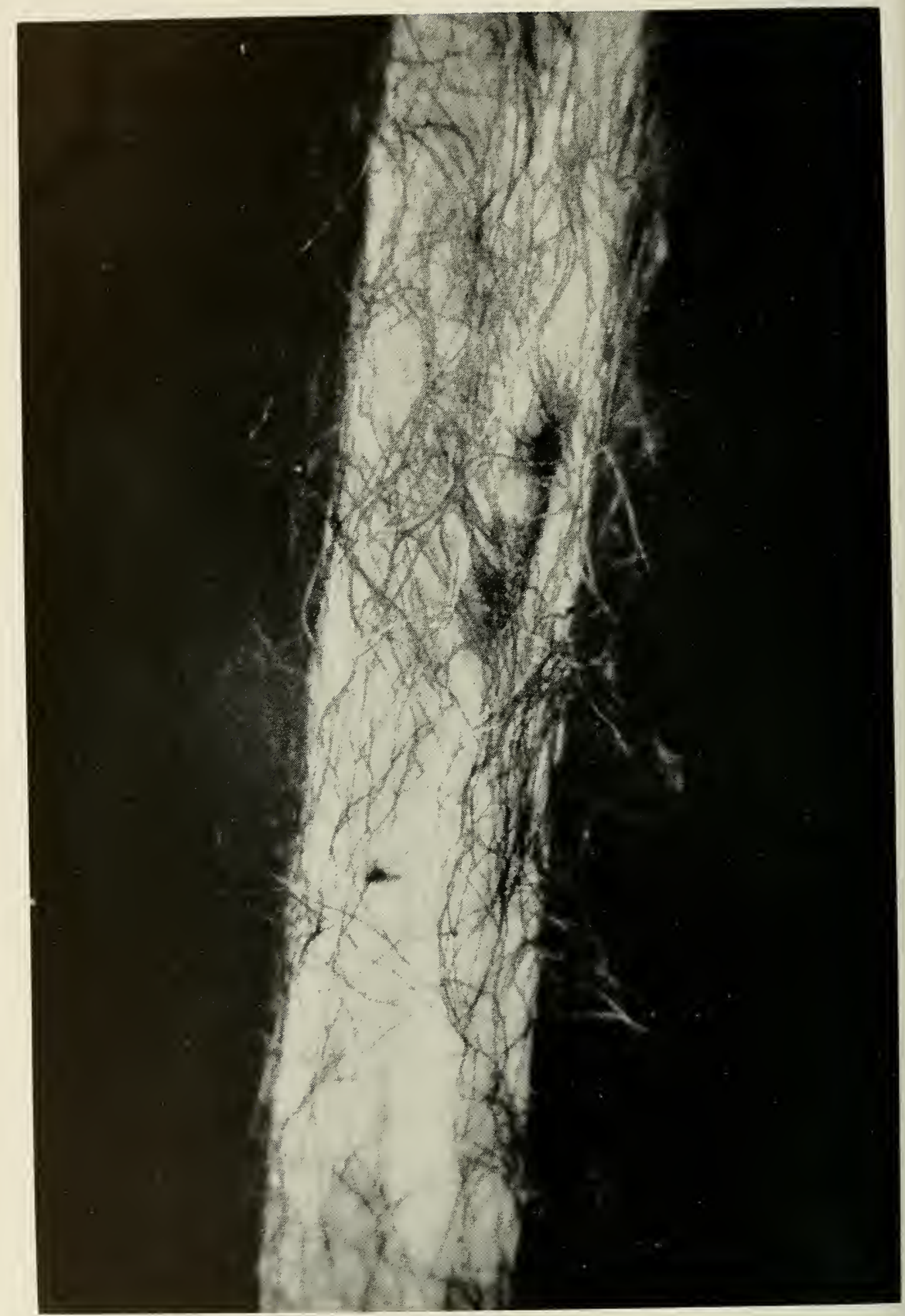

FIGURE 10. ENLARGED SECTION of a clover stem showing the large black aerial mycelium of the blackpatch fungus. 


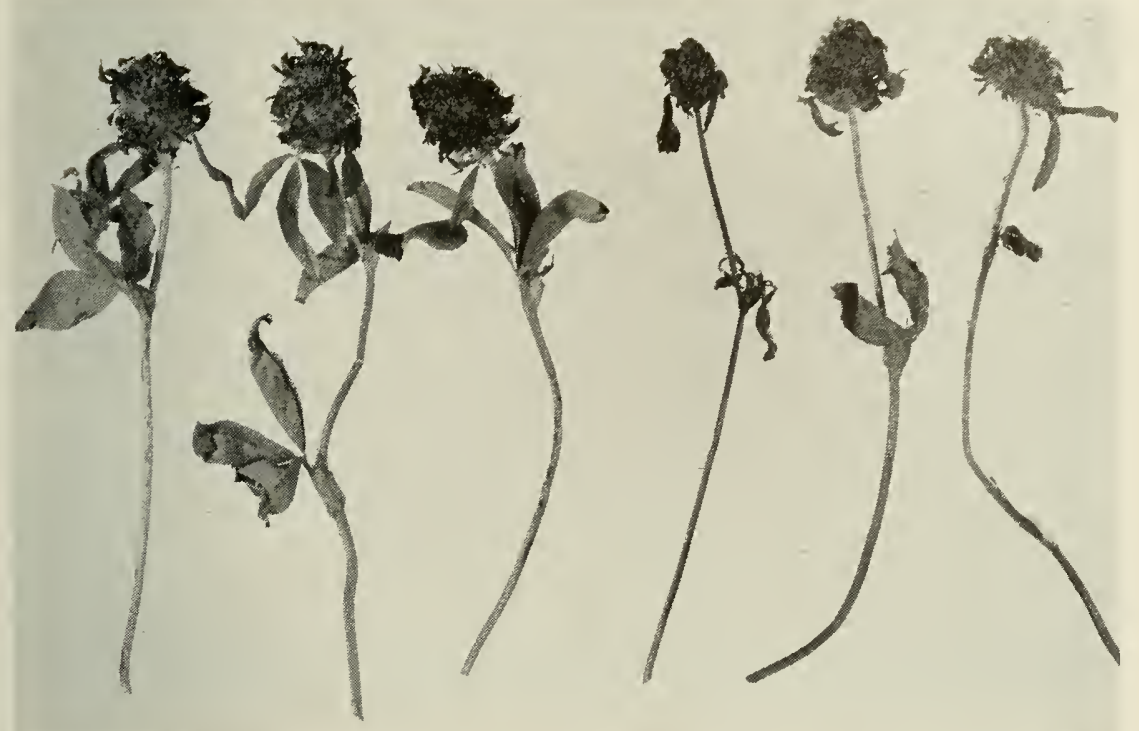

FIGURE 11. THREE NORMAL red clover heads in early stages of maturity (left) and three heads in the same stage of maturity but infected by the blackpatch fungus (right). Note aerial mycelium on the petioles just below the heads.

on the top portion of the stem has no surface mycelium connection with lower parts of the plant. It is believed that these isolated areas are infected at the time the stem is produced at the crown and are carried up with the elongation of the stem.

Infected flower heads usually are smaller than those free from the fungus (Figure 11). The first two leaves directly below infected heads usually are killed and therefore serve as an additional indication that the head is infected. The death of plant parts and subsequent browning and drying due to widespread blackpatch infections soon after the full-bloom stage of growth has been confused by farmers with normal but early ripening. Clover fields to be harvested for seed, when heavily infected with blackpatch, have appeared to be at the proper stage for cutting one or more weeks before the normal date.

\section{Seed Transmission}

Chilton (7) reported isolating the blackpatch fungus from surface-sterilized red clover seed. Only a small proportion of the seed tested yielded this fungus. The present study has indicated that a large number of the seeds from heavily infected fields carry 
the fungus. The fungus mycelium often can be observed on the surface of the seeds (Figure 12). If the fungus reaches the flower head after the seed has started to harden, the mycelium may grow over the seed coat and adhere to it so tightly that it remains there after the seed has been hulled. If the seed is softer at the time that the fungus reaches it, the mycelium may penetrate under the seed coat or even deeper into the seed. Many of the seeds that have the fungus mycelium inside are not viable, but serve as a source of inoculum when planted with good seed in the field. These seed generally are brown and shriveled, like those illustrated in Figure 13.

A number of other fungi occur on the seed coat and may be mistaken for the blackpatch fungus. A species of Alternaria is similar in color but lacks the massive appearance of the blackpatch mycelium. A species of Cladosporium also occurs very frequently but its mycelium usually is lighter in color (Figure 14). The blackpatch fungus was the only one visible on the seed coat which proved to be pathogenic.

When a seed carrying the blackpatch mycelium germinates, the emerging plant is killed by the fungus. The aerial mycelium arising from the infected seed coat penetrates any part of the seedling with which it comes in contact (Figure 15), and causes a rapid damping-off similar to that resulting from invasion by species of Rhizoctonia. The new plant may be killed at any stage of germination with some even failing to break out of the seed coat. The location of the mycelium in or on the seed probably determines how far the seedling can develop before it is killed. Seeds that are not viable, but still contain the fungus, serve as a source of inoculum as the mycelium grows from them and attacks any near-by developing seedlings.

A damping-off of seedlings due to infection by the blackpatch fungus was observed in the field on one occasion; much of the killing is probably not evident since many seedlings would be killed before they emerge from the ground.

An attempt was made to determine whether or not the blackpatch fungus winters in the soil or in debris on the surface of the ground. Red clover seed free of the fungus was planted in soil collected in early spring from a clover field that had been heavily infected with blackpatch the previous summer. The flats containing the soil and seed were then placed in a chamber where the conditions of temperature and humidity approximated the optimum requirements of the fungus. It was believed that if the 


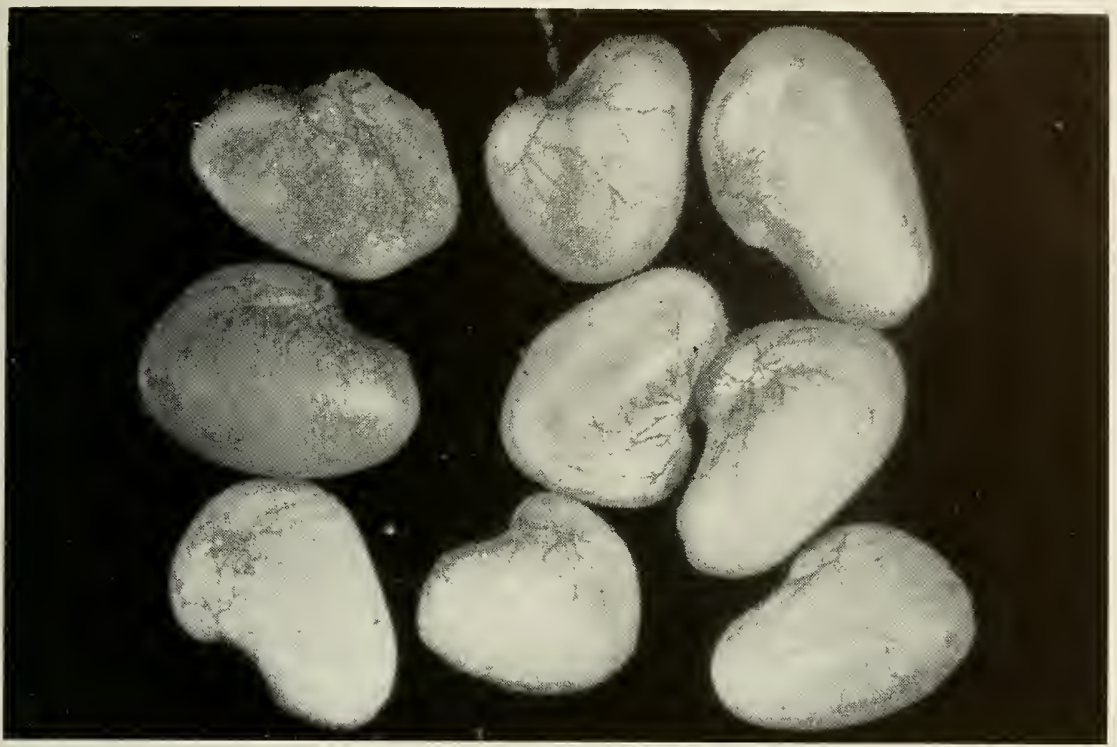

FIGURE 12. RED CLOVER seeds lightly infected by blackpatch. Note the large black mycelium of the fungus radiating from the hilum over the surface of the seeds. Such seeds usually are slightly shrivelled but nearly always viable.

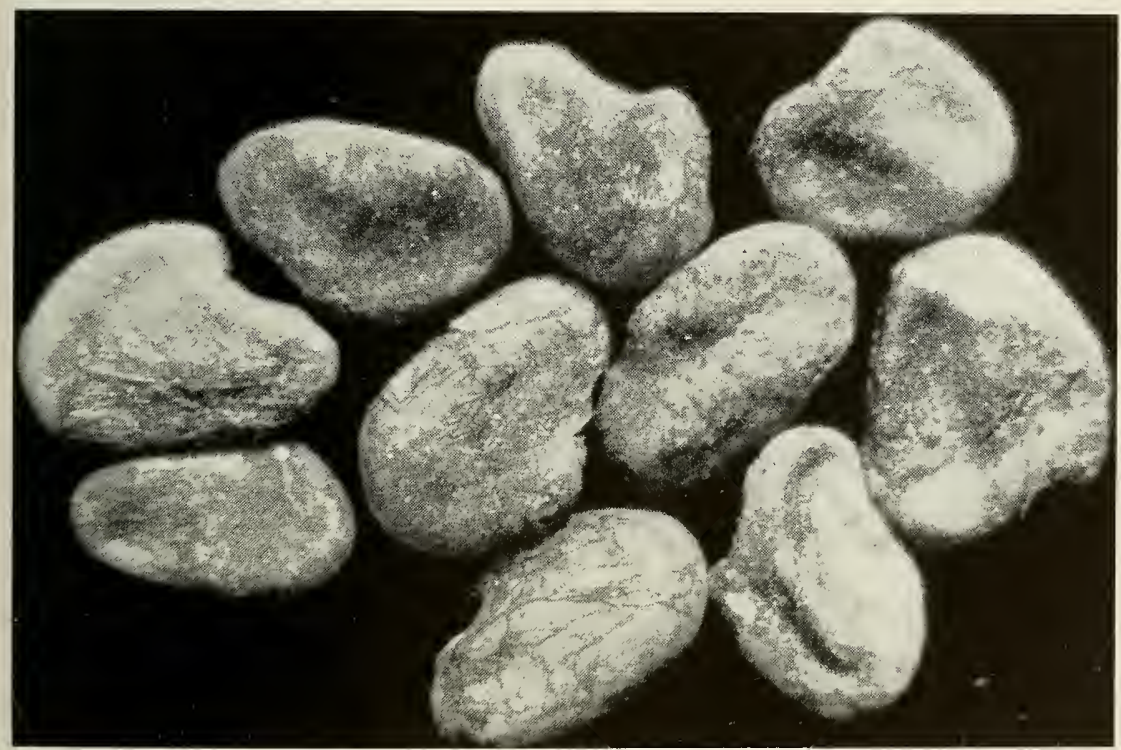

FIGURE 13. TEN SEVERELY INFECTED red clover seeds showing the mycelium that has penetrated and grown under the seed coat. Such seeds are shrivelled, discolored and often dead but some may still be viable. 


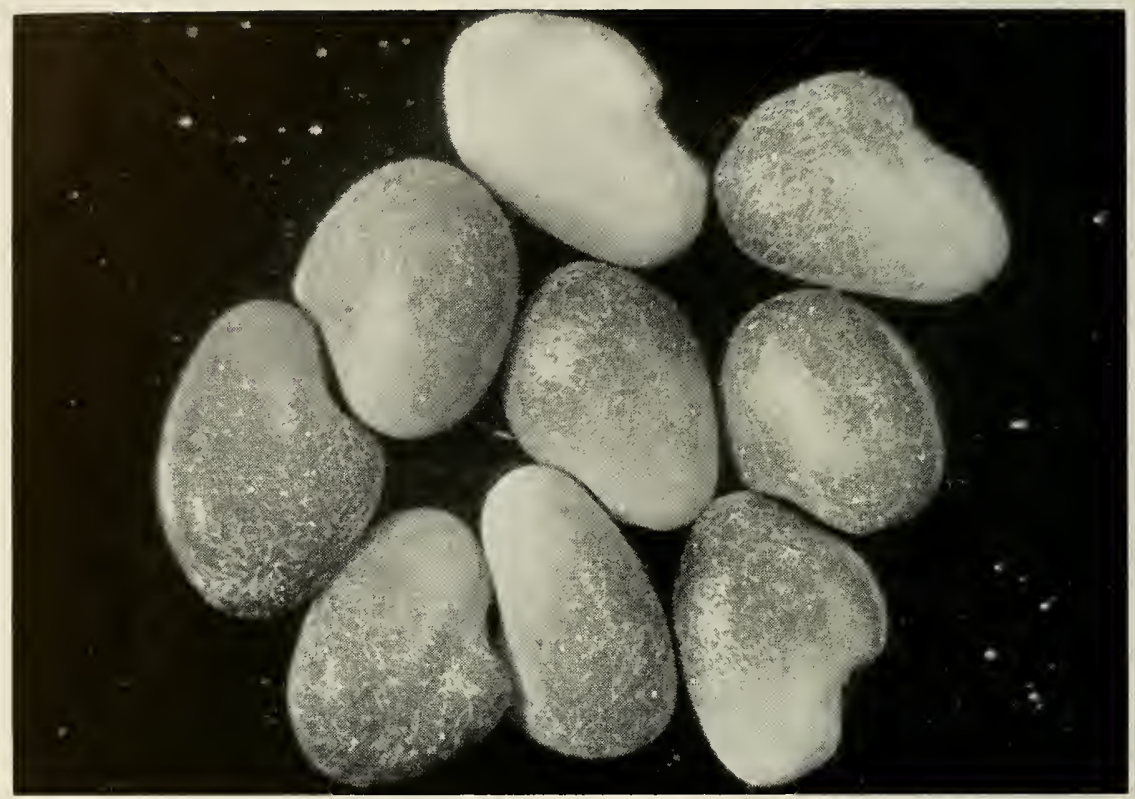

FIGURE 14. RED CLOVER seeds showing surface infection by non-pathogenic fungi. Such seeds usually are plump and uninjured.

fungus were present in the soil it would, with renewed growth, eventually contact some of the germinating seedlings. Isolations from killed seedlings produced a species of Rhizoctonia, but the blackpatch fungus was not found. Clover straw and other debris also collected in the spring from the same field produced no blackpatch infections on seedlings when it was mixed with the soil.

Since the fungus mycelium on the seeds will renew growth after being held under seed-storage conditions for two years, it seems probable that it also would be able to withstand winter conditions on seeds that remain in the field and overwinter in or on the soil.

\section{INFLUENCE ON THE SEED Yield}

A survey of one clover field heavily infected with blackpatch indicated that more than 50 per cent of the blossom heads had been attacked. The diseased flower heads might produce no seed if they had been infected early, a normal seed yield if infected late, or quantities between the two extremes.

To determine the effect of blackpatch head infections on the seed yield, three samples of 100 clover heads each were collected. 


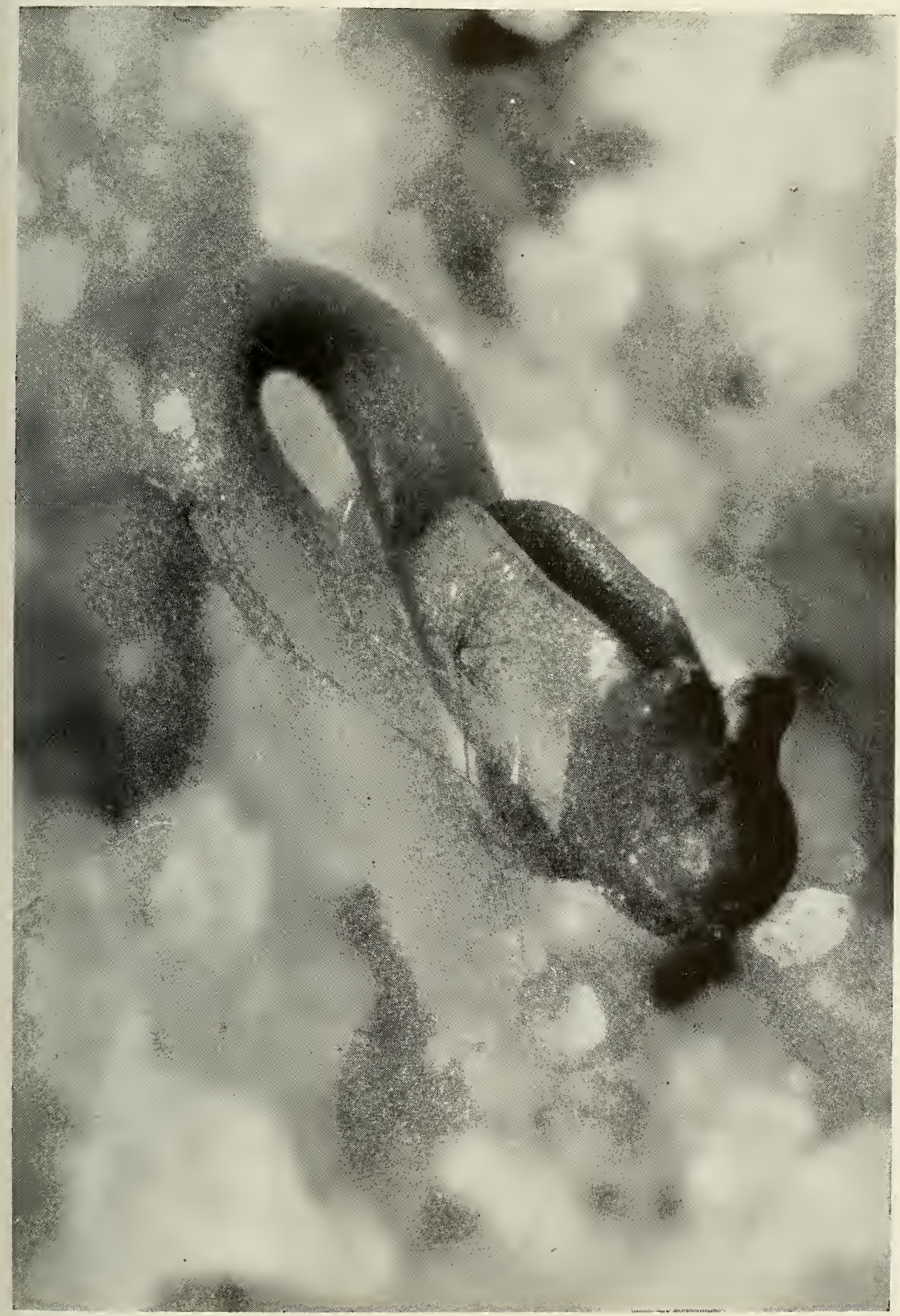

FIGURE 15. GERMINATING red clover seedling arising from seed such as those in Figure 12. Note the black mycelium of blackpatch fungus that has grown out from the seed coat and is infecting one of the cotyledons and the hypocotyl. 
One sample consisted of heads infected with blackpatch; a second was from the same field but the heads apparently were not diseased; and the third sample was from a field two or three miles away where no blackpatch had been found. The seed was threshed from the heads and separated into two groups; one of good seed and a second in which all shriveled and immature seed was placed. The total number and weight of good and bad seeds is presented in Table 6. Tubes containing the seed samples are shown in Figure 16. The data indicate that the seed yield may be seriously reduced by epiphytotics of the blackpatch disease.

TABle 6. Red Clover Seed Yield from Head Samples Infected with Blackpatch-and Free of Blackpatch

\begin{tabular}{|c|c|c|c|c|}
\hline \multirow[b]{2}{*}{ SAMPLE } & \multicolumn{2}{|c|}{ Total Number of SeEds } & \multicolumn{2}{|c|}{$\begin{array}{c}\text { Total Weight of SeEds } \\
\text { in Grams }\end{array}$} \\
\hline & Good SEED & $\begin{array}{c}\text { IMMATURE } \\
\text { AND SHRIVELED } \\
\text { SEED }\end{array}$ & GOOD SEED & $\begin{array}{c}\text { IMMATURE } \\
\text { AND SHRIVELED } \\
\text { SEED }\end{array}$ \\
\hline $\begin{array}{l}100 \text { Seed Heads Infected } \\
\text { with Blackpatch }\end{array}$ & 2136 & 2620 & 2.93 & 1.94 \\
\hline $\begin{array}{l}100 \text { Non-Infected Seed } \\
\text { Heads from Infected Field }\end{array}$ & 3037 & 1348 & 4.24 & 0.96 \\
\hline $\begin{array}{l}100 \text { Seed Heads from a } \\
\text { Field Free of Blackpatch }\end{array}$ & 3606 & 423 & 5.71 & 0.34 \\
\hline
\end{tabular}

An experienced grower noted that one blackpatch-infected clover field should have produced about three bushels of seed per acre on the basis of the dense stand present, but the yield obtained was approximately one bushel per acre. This observation agrees closely with the data obtained from seed counts.

Farmers have found that the best clover seed yields have been obtained after relatively dry growing seasons. Data on the rainfall during the summer months in eastern West Virginia indicate that a greater seed yield is obtained in the years having the least rainfall. Blackpatch is undoubtedly one of the major factors that reduce yields during wet seasons.

\section{CONTROL}

Several fungicides were tested in the laboratory and greenhouse to determine whether any of them would effectively con- 


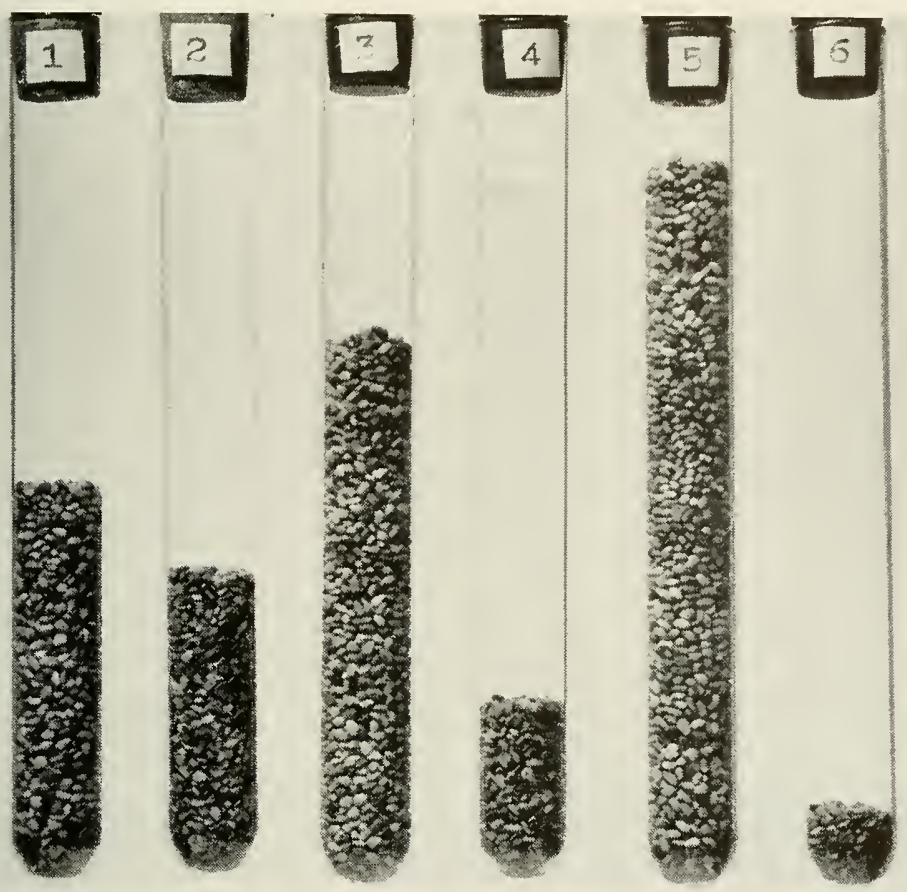

FIGURE 16. SEED YIELDS of three lots of 100 seed heads. (1) and (2) Plump and healthy seeds, and shrivelled and diseased seeds from 100 heads infected with blackpatch. (3) and (4) Plump and shrivelled seeds respectively from 100 apparently healthy heads from the same field. (5) and (6) Plump and shrivelled seeds from 100 heads collected from a field apparently free from blackpatch.

trol the blackpatch fungus on red clover. The fungicides tested in the laboratory included Bioquin 1, Bioquin 100, copper mercaptobenzothiazole, manganese ethylene bis dithiocarbamate, Fermate, and tribasic copper sulphate. The object was to determine what effect these fungicides would have on the blackpatch fungus when incorporated in the medium on which it was growing. Before autoclaving, various quantities of the standard fungicide solution were added to the 2 per cent malt extract medium contained in Petri dishes. The dishes were inoculated in the center of the dish after the medium had cooled. The diameter of the colony in each plate was measured after one week. The data obtained are shown in Table 7. These tests indicated that Bioquin 1 and Fermate were possible agents for controlling the fungus on clover.

A small-scale greenhouse test was made to determine the effectiveness of these same fungicides in controlling blackpatch on potted clover plants. Pots containing a number of six-month-old 
Table 7. Growth of Blackpatch Fungus, Measured by Diameter of Colony in Inches, After Seven Days on a Medium Containing Various Fungicides

\begin{tabular}{|c|c|c|c|c|}
\hline \multirow[b]{2}{*}{ Fungicide } & \multicolumn{4}{|c|}{ Milliliters of Standard Spray Solution } \\
\hline & 1.0 & $\overline{0.5}$ & 0.1 & 0.0 \\
\hline & \multicolumn{4}{|c|}{ GRowth IN INChES } \\
\hline Bioquin 1 & 0 & 0 & 0 & $21 / 2$ \\
\hline Bioquin 100 & 0 & $7 / 8$ & $13 / 8$ & $2 \frac{1 / 4}{4}$ \\
\hline Copper Mercaptobenzothiazole & $1 \frac{1 / 2}{2}$ & $15 \%$ & $21 / 8$ & $2 \frac{1}{4} 4$ \\
\hline Manganese ethylene bis dithiocarbamate & 2 & $23 / 8$ & $23 / 8$ & 23,8 \\
\hline Tribasic copper sulphate & 13,8 & 2 & $21 / 4$ & 23,8 \\
\hline Fermate & 0 & 0 & $5 / 8$ & $21 / 8$ \\
\hline
\end{tabular}

red clover plants were sprayed with the fungicides in the recommended concentration. After the fungicide had dried, the plants were sprayed with blackpatch inoculum. Inoculum was prepared by mincing the fungus mycelium in water in a Waring blendor after the liquid medium on which it had grown was removed by straining. The inoculated pots were then placed in a chamber in which the humidity and temperature were maintained at about the optimum for the growth of the fungus. After fifteen days, the effectiveness of the fungicide in controlling the blackpatch fungus was noted as follows: Fermate, good; Bioquin 1, excellent; tribasic copper sulphate, good, but extensive copper injury was present; Bioquin 100, no control; copper mercaptobenzothiazole, no control; manganese ethylene bis dithiocarbamate, poor control. Pots of clover that had been inoculated with the fungus, but not sprayed with a fungicide, showed a heavy infestation of the disease. Bioquin 1 appeared to be the most effective fungicide in controlling blackpatch under greenhouse conditions.

The control of blackpatch on the red clover seed crop by means of a fungicide may be practical under some conditions. In 1950, experimental plots were located in a seed field and treated periodically with fungicides in combination with an insecticide. Dry weather conditions in the region did not favor the development of the disease so no control data were obtained. A few scattered spot infections were present in the plots, but they remained localized and did not reach the flower heads. The scattered infections appeared rather uniform in all of the plots regardless of the treatment. The seed yield, based on the weight of the seed obtained from two hundred heads harvested from each plot, is shown in 
Table 5. Additional information on these plots is included in the section on insect control.

Although no data from the field were obtained in 1950 to support the work carried out in the greenhouse, it is believed that fungicides will provide some protection to flower heads and developing seed during wet seasons.

As with any field crop of this type, the most satisfactory way to control a disease is to use resistant plants. To date, however, no evidence of resistance to the blackpatch disease has been found in red clover.

Another possible means of controlling blackpatch is by seed treatment. If the fungus is carried over from year to year on the seed and does not remain viable in the field through the winter months, seed treatment or the use of clean seed from other regions may be the most effective method of control. However, since blackpatch is as prevalent in second-year clover fields as it is in the first season crop, the fungus does overwinter in the field. Furthermore, the disease has been observed on volunteer seedlings, indicating that it can live over winter in the soil on infected seed. In spite of this, seed treatment may still be of value in cutting down the amount of inoculum present from year to year.

Red clover seed carrying the blackpatch fungus should not be seeded in regions where the disease is not already present. The seed produced in eastern West Virginia is generally used locally, a large part of the yield often being seeded on the farm where it is produced. Use of home grown seed year after year may have tended to build up the disease, particularly if the fungus is carried over on the seed. Seed harvested from heavily infected fields probably would carry a large amount of the fungus, whereas that harvested from lightly infected fields would be almost free from the disease. It may be advisable to harvest the crop for seed only during the years when the disease does not reach the flower heads. Whether or not and to what extent the fungus overwinters in the field and the effectiveness of seed treatment in the field will influence any recommendation on the use of home grown seed in the area. 


\section{LITERATURE CITED}

1. Anonymous, "Clover Injured by Root Borer Killed by Disease." Penn. Agr. Exp. Sta. Ann. Rpt. 61, 1948.

2. Anonymous, "Blackpatch of Clover." Ky. Agr. Exp. Sta. Ann. Rpt. $46: 30,1933$.

3. Aamodt, O. S., Delwiche, E. J., and Stone, A. L., Home Grown Red Clover Seed Best. Wis. Agr. Ext. Circ. 289:1-11, 1937.

4. Arnott, D. A., "The Clover Seed Weevils, Tychius picirostris Fabricus and Tychius griseus Schaeffer as Pests of Clover Seed in Southwestern Ontario." Ann. Rpt., Entom. Soc. Ontario 1947, pp. 47-50, 1948.

5. Bird, J. N., "Seed Setting in Red Clover." Amer. Soc. Agron. Jour., 36:346-357 (1944).

6. Blatchley, W. S., and Leng, C. W., Rynchophora or Weevils of North Eastern America. Indianapolis. The Nature Publishing Company, 1916.

7. Chilton, J. P., "Some Pathogenic Fungi Occurring in the Seed of Red and Subterranean Clover." Phytopath., 32:738-739 (1942).

8. Cooper, W. E., "Frost Heaving and Damage to Black Locust Seedlings." Ecol., 21:501-504 (1940).

9. Dudley, J. E., and Bronson, T. E., "The Pea Aphid on Peas and Methods for Its Control." U.S.D.A. Farm Bull. 1945:1-14 (1943).

10. Feene, S. B., "Winter Injury to Clover and Alfalfa in Virginia." Plant Disease Reporter, 31:281-282 (1947).

11. Fergus, E. N., An Analysis of Clover Failure in Kentucky. Ky. Agr. Exp. Sta. Res. Bull. 324:443-476, 1931.

12. Fergus, E. N., and Valleau, W. D., A Study of Clover Failure in Kentucky. Ky. Agr. Exp. Sta. Bull. 269: 143-210, 1926.

13. Fleetwood, J. Ross, Red Clover. Mo. Agr. Ext. Serv. Circ. 548:1-4, 1947.

14. Folsom, J. W., The Insect Pests of Clover and Alfalfa. Ill. Agr. Exp. Sta. Bull. 134: 113-197, 1909.

15. Garman, Philip, Tetranychidae of Connecticut. Conn. Agr. Exp. Sta. Bull. 431:67-88, 1940.

16. Gilbert, A. H., and Myer, D. S., Stem Rot of Clovers and Alfalfa as a Cause of Clover Sickness. Ky. Agr. Exp. Sta. Circ. 8:46-59, 1915.

17. Herrick, G. W., and Detwiler, J. D., "Notes on Some Little Known Pests of Red-Clover." Jour. Econ. Ent., 12:206-209 (1919).

18. Heusinkveld, David, Red Clover for Illinois. Ill. Agr. Ext. Serv. Circ. 627:1-23, 1948.

19. Hollowell, E. A., "Influence of Atmosphere and Soil Moisture Upon Seed Setting in Red Clover." Jour. Agr. Res., 39:229-247 (1929).

20. Hollowell, E. A., Why Red Clover Fails. U.S.D.A. Agr. Leaflet 110:1-6, 1934.

21. Hollowell, E. A., "Clovers That Make a Crop." U.S.D.A. Yearbook 1948:360-363, 1948.

22. Jeppson, L. R., and MacLeod, G. F., "Lygus Bug Injury and Its Effect on the Growth of Alfalfa." Cal. Agr. Exp. Sta. Hilgardia, 17:165-188 (1946).

23. Jewett, H. H., The Clover Root Curculio. Ky. Agr. Exp. Sta Circ. 42: 15-23, 1934.

24. Jewett, H. H., Leafhopper Pest of Clover and Alfalfa. Ky. Agr. Exp. Sta. Circ. 44:107, 1936.

25. Johnson, E. M., and Valleau, W. D., Blackstem of Alfalfa, Red Clover and Sweet Clover. Ky. Agr. Exp. Sta. Bull. 339:57-82, 1933.

26. Kilpatrick, R. A., and Hanson, E. W., "Root and Crown Rots of Red Clover in Wisconsin. Phytopath, 40:16 (1950). 
27. Kreitlow, K. W., and Hanson, R. G., "Role of Fusarium in Loss of Red Clover Stands." Phytopath, 40:16 (1950).

28. Linsley, E. G., and MacSwain, J. W., "The Effects of DDT and Certain Other Insecticides on Alfalfa Pollinators." Jour. Econ. Ent., 40:358363 (1947).

29. Marshall, D. S., and others, "Control of the Clover Root Borer." Jour. Econ. Ent., 42:315-318 (1949).

30. Medler, J. T., and Chamberlin, T. R., Seed Yields of Red Clover and Alfalfa. Ill. Agr. Exp. Sta. Bull. 134:113-197, 1909.

31. Megee, C. R., and Kelty, R. H., "The Influence of Bees Upon Clover and Alfalfa Seed Production." Mich. Agr. Exp. Sta. Quarterly Bull., 14:271-279 (1932).

32. Megee, C. R., Frakes, M. G., and Larsen, I. T., "The Influence of Clipping Treatment and Rolling on the Yield of Clover Seed." Jour. Amer. Soc. Agron., 34:841-843 (1942).

33. Osborne, H. T., "Vein-mosaic of Red Clover." Phytopath., 27:10511058 (1937).

34. Pederson, C. E., "Insecticides Increase Legume Seed." Mich. Agr. Exp. Sta. Quarterly Bull., 30:298-308 (1948).

35. Pieters, A. J., and Hollowell, E. A., "Clover Improvement." U.S.D.A. Yearbook 1937:1190-1214, 1937.

36. Pieters, A. J., and Hollowell, E. A., Clover Failure. U.S.D.A. Farmers Bull. 1936: 1-24, 1924.

37. Rockwood, L. P., The Clover Root Borer. U.S.D.A. Dept. Bull. 1426: $1-48,1926$.

38. Scholl, J. M., and Medler, J. T., "Spittle Bugs in Relation to Alfalfa Seed Production in Wisconsin." Jour. Econ. Ent., 40:446-448 (1947).

39. Schwardt, H. H., Newsom, L. D., and Norton, L. B., "Increasing Red Clover Yields by Treatment with DDT or Hexachlorocyclohexane." Jour. Econ. Ent. 40:363-365 (1947).

40. Smith, O. F., "A Leaf Spot Disease of Red and White Clovers." Jour. Agr. Res., 54:591-599 (1937).

41. Smith, O. F., "Stemphylium Leaf Spot of Red Clover and Alfalfa." Jour. Agr. Res., 61:831-846 (1940).

42. Thompson, Victor C., The Value of Bees to Agriculture. Ark. Agr. Exp. Sta. Mimeo. Series 1, 1949.

43. Tower, D. G., and Fenton, F. A., Clover-leaf Weevil. U.S.D.A. Bull. 922: $1-18,1920$.

44. Valleau, W. D., Fergus, E. N., and Henson, Lawrence, Resistance of Red Clovers to Sclerotinia trifoliorum Erik, and Infection Studies. Ky. Agr. Exp. Sta. Bull. 341:115-131, 1933.

45. Weaver, C. R., "Improvement in Hay Yields Resulting from Control of the Meadow Spittle Bug." Jour. Econ. Ent., 43:7-11 (1950).

46. Wehrle, P. L., The Clover-flower Midge. N. Y. (Ithaca) Agr. Exp. Sta. Bull. 481:3-35, 1929.

47. Weimer, J. L., "Blackpatch of Soybean and Other Forage Legumes." Phytopath., 40:782-783 (1950).

48. Willard, C. J., Cutler, J. S., and McLaughlin, J. B., "The Time of Cutting the True Clovers." Ohio Agr. Exp. Sta. Bi-Monthly Bull. 19:39-43 (1934).

49. Wilsie, C. P., and Hollowell, E. A., Effect of Time of Cutting Red Clover on Forage Yields, Seed Setting and Chemical Composition. Iowa Agr. Exp. Sta. Res. Bull. 357:639-668, 1948. 
